\title{
Gene therapy for malignant glioma
}

\author{
Hidehiro Okura ${ }^{1,2}$, Christian A Smith ${ }^{1}$ and James T Rutka ${ }^{1,3,4^{*}}$
}

\begin{abstract}
Glioblastoma multiforme (GBM) is the most frequent and devastating primary brain tumor in adults. Despite current treatment modalities, such as surgical resection followed by chemotherapy and radiotherapy, only modest improvements in median survival have been achieved. Frequent recurrence and invasiveness of GBM are likely due to the resistance of glioma stem cells to conventional treatments; therefore, novel alternative treatment strategies are desperately needed. Recent advancements in molecular biology and gene technology have provided attractive novel treatment possibilities for patients with GBM. Gene therapy is defined as a technology that aims to modify the genetic complement of cells to obtain therapeutic benefit. To date, gene therapy for the treatment of GBM has demonstrated anti-tumor efficacy in pre-clinical studies and promising safety profiles in clinical studies. However, while this approach is obviously promising, concerns still exist regarding issues associated with transduction efficiency, viral delivery, the pathologic response of the brain, and treatment efficacy. Tumor development and progression involve alterations in a wide spectrum of genes, therefore a variety of gene therapy approaches for GBM have been proposed. Improved viral vectors are being evaluated, and the potential use of gene therapy alone or in synergy with other treatments against GBM are being studied. In this review, we will discuss the most commonly studied gene therapy approaches for the treatment of GBM in preclinical and clinical studies including: prodrug/suicide gene therapy; oncolytic gene therapy; cytokine mediated gene therapy; and tumor suppressor gene therapy. In addition, we review the principles and mechanisms of current gene therapy strategies as well as advantages and disadvantages of each.
\end{abstract}

Keywords: Glioblastoma, Gene therapy, Prodrug suicide, Oncolytic, Cytokine mediated, Tumor suppressor gene

\section{Review Introduction}

Gliomas are the most frequently occurring primary brain tumor in adults. Glioblastoma multiforme (GBM) is the most aggressive form and least curable [1]. The current standard of treatment consists of maximal surgical resection followed by radiation and temozolomide (TMZ) chemotherapy [2]. Despite recent reports that demonstrate a two-month survival advantage when adjuvant TMZ chemotherapy is used, the median survival still remains less than 15 months and death ensues in most cases within 2 years of diagnosis [3,4]. The high mortality observed with GBM is due to a consequence of many contributing factors including the aggressive and invasive

\footnotetext{
* Correspondence: james.rutka@sickkids.ca

'The Arthur and Sonia Labatt Brain Tumour Research Centre, The Hospital for Sick Children, Peter Gilgan Centre for Research and Learning, 686 Bay Street, 17th Floor, Toronto, ON M5G OA4, Canada

${ }^{3}$ Department of Surgery, University of Toronto, 149 College Street, 5th Floor Toronto, Ontario M5T 1P5, Canada

Full list of author information is available at the end of the article
}

phenotype making radical surgical removal extremely difficult. In addition, GBM is often resistant to radiation and/ or chemotherapy. Chemotherapy may fail because of an inability to effectively deliver reagents across the blood brain barrier (BBB). The central nervous system is also largely regarded as an immunologically privileged site, and protected from systemic immune responses. This presents a disadvantage with respect to the efficacy of systemic immune-boosting strategies.

It is now generally accepted that all cancers contain a small population of cells with stem cell like properties called cancer stem cells (CSCs). The concept of the CSC has been extended to brain tumors, including GBM, and it is now being exploited as a therapeutic target. Glioma stem cell (GSCs) are capable of asymmetric cell division into self-renewing GSCs and differentiating daughter cells that can gain different phenotypes, subsequently losing their multipotent property [5]. Disease progression and an inevitable recurrence after therapy are most 
likely attributed to GSCs which are highly invasive and resistant to radiotherapy and chemotherapeutic agents [6-8]. Unfortunately, despite the significant progress achieved by surgery and adjuvant chemoradiotherapy including molecular-targeted approaches in the treatment of disseminated malignancies, the prognosis of GBM remains unsatisfactory. Therefore, novel and more efficient strategies are urgently needed, and real progress can only emerge from increasing our understanding of the molecular biology of these tumours, and through the discovery of novel mechanisms for the delivery of tumoricidal agents.

Gene therapy can be defined as the treatment of disease by the introduction of a therapeutic gene or the manipulation of a disease-related gene such as abrogation of an activated oncogene within target cells [9]. Owing to a better understanding of the mechanisms of virus interactions with the cell and the advancement of recombinant deoxyribonucleic acid (DNA) technology, it is now possible to take advantage of the tumor cell-specific genetic defects and to construct viral strains that replicate selectively in tumor cells. To date, gene therapy has been applied to several types of cancer [10]. One of the most dismal types of cancer, GBM is an ideal target for gene therapy given that current standard therapies remain minimally effective and that GBM rarely metastasizes to other locations in the body.

The first clinical trials of gene therapy targeting gliomas were published in the 1990's [11,12]. Different methods, including: viral vectors; cellular carriers (neural stem cell, mesenchymal stem cell, or embryonic stem cell); and synthetic vectors using nanotechnology (nanoparticle or cationic liposome) have been studied and employed as a vehicle to deliver genes into the target cells. Although stem cells as vehicles have only recently reached clinical study, they promise to be one of the most attractive vectors to combine gene therapy with other type of therapies. The only synthetic vector that has reached clinical trials against glioma to date is a cationic liposome which was employed as a small molecule carrier [13,14]. Although, gene transfer using liposomes is considered safe, it has been used infrequently due to limited gene transfer efficiency. On the other hand, viral vectors are considered to be the most effective of all gene delivery methods for in vivo gene transfer [15]. Currently, the most frequently used DNA delivery vehicles are genetically modified viruses or vectors. There are two types of viral vectors used for anti-glioma therapy. The first uses replication-deficient viruses capable of transducing genes into the tumor cells resulting in detrimental intracellular effects; and the second employs oncolytic viruses where the replicating viruses have a lytic cycle, and selectively kills tumor cells. Among all viral vectors, adenovirus (AV), retrovirus, herpes simplex virus (HSV), and adeno-associated virus (AAV) are currently the most widely employed delivery vectors used in gene therapy in patients with cancer $[15,16]$.

There are a wide variety of strategies for gene therapy of GBM. In addition to the large number of vectors and their individual features, different transgenes provide distinct ways of eliciting an anti-tumoral response. Consequently, gene therapy is a viable option for the treatment of GBM. In this article, we will review (i) the major approaches used for gene therapy against GBM including prodrug/suicide gene therapy, oncolytic gene therapy, cytokine mediated gene therapy, and tumor suppressor gene therapy; (ii) the rationale for the design of vectors; (iii) mechanisms of the vectors replication in tumor cells; (iv) discuss advantages and disadvantages of each gene therapies and future direction.

\section{Approaches to gene therapy Suicide gene therapy}

The most commonly used gene therapy strategy against malignant glioma in preclinical study and in clinical trials is suicide gene therapy [17]. Suicide gene therapy is a strategy that involves introduction of a viral or a bacterial gene into tumor cells resulting in the conversion of a nontoxic compound into lethal active molecules capable of inducing tumor cell death [18]. A critical factor in this strategy is that the gene encodes an enzyme which converts a prodrug into a cytotoxic drug. More importantly, this strategy is based on evidence that prodrug-activating enzymes are normally absent or expressed at low levels in mammalian cells [19]. Consequently the tumor-targeting viral vector is necessary to restrict enzyme expression to the transduced tumor cells. Several suicide gene therapies have been evaluated using adenoviral, retroviral, or non-viral vector delivery methods in numerous clinical trials [17,20-24]. The most widely investigated suicide gene therapies against GBM are Herpes Simplex Virus Thymidine Kinase (HSV-TK) gene therapy and Cytosine Deaminase 5-fluorocytosine (CD/5-FC) [13,17,25-27].

The possibility of using HSV-TK as gene therapy was first reported by Moolten in 1986 [28]. HSV-TK can catalyze the phosphorylation of nucleoside analogues such as ganciclovir (GCV: a synthetic analogue of 2'deoxy-guanosine) which is a poor substrate for the mammalian TK. Following the systemic administration of the inactive prodrug, GCV is converted by HSV-TK into a toxic metabolite called GCV-triphosphate which is incorporated into the DNA of actively proliferating cells (Figure 1). GCV-triphosphate consequently blocks DNA replication and inhibits cell division [28,29]. Apoptosis underlies the mechanism of cytotoxicity induced by the HSV-TK/GCV gene therapy [30]. The HSV-TK gene therapy is cell cycle dependent. Therefore, one of the advantages of this therapy is that it exhibits selective cytotoxicity to only actively dividing cells transduced 


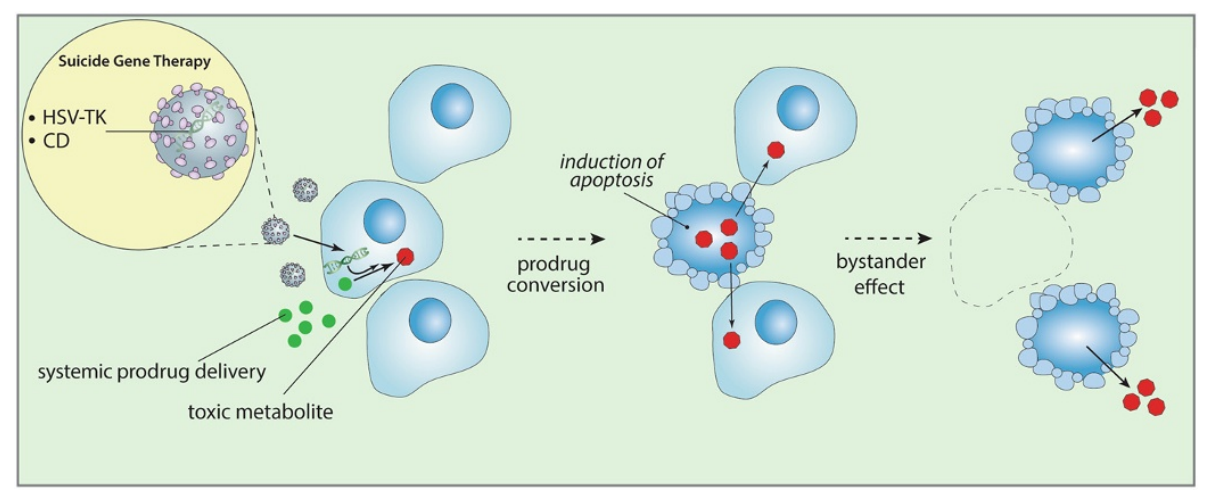

Figure 1 Strategy for suicide gene therapy. The aim of suicide gene therapy strategy is to increase the delivery of toxic metabolites to tumor cells and result in efficient cell death. Initially, a gene encoding a prodrug-activating enzyme is delivered by a tumor-targetting viral vector. Subsequent systemic administration of an inactive prodrug results in generation of a toxic metabolite and cell death of the transduced cells and non-trasduced bystander tumor cells (bystander effect) only at the tumor site.

with HSV-TK. The other advantage is the so-called bystander effect where toxicity is transferred directly from infected cells to adjacent non-infected cells thereby enhancing the treatment effect [31]. A possible mechanism that can account for this effect is that non-transduced cells are killed by the spread of phosphorylated nucleoside analogues through gap-junctions, facilitated by cell-to-cell contacts [15,32-34]. A second possible mechanism is the accumulation of phosphorylated nucleoside analogues in neighboring cells inducing apoptosis of non-transduced cells $[35,36]$. A third mechanism may involve phagocytosis induced by neighboring transduced cells as a result of apoptotic vesicle formation. Several cellular components could be shared with the neighboring cell during this process resulting in the delivery of an apoptotic signal [37].

HSV-TK/GCV gene therapy has demonstrated promising results in animal models [12,38]. Recently, these results have prompted clinicians to examine HSV-TK/ GCV gene therapy for glioblastoma. Multiple Phase I and II clinical trials demonstrated that HSV-TK/GCV gene therapy is a relatively safe strategy $[21,39]$. There is some evidence, however, suggesting that HSV-TK transduced cells may become resistant to the prodrug, therefore requiring combination of suicide gene therapy with chemo-radiotherapy [25,40-42]. One of the largest randomized Phase III clinical trials was conducted by Rainov, where 248 patients with newly diagnosed, previously untreated GBM, were randomized into a control group (surgical resection and radiotherapy) or gene therapy group (surgical resection and radiotherapy plus adjuvant replication-competent retrovirus mediated HSVTK/GCV gene therapy during surgery). Although this trial proves that HSV-TK gene therapy was safe, there was no difference in median survival and tumor progression between groups. Unfortunately, based on these data, there was no therapeutic benefit of retrovirus mediated HSV-TK gene therapy. The authors concluded that improved high efficiency delivery and distribution strategy of therapeutic genes is likely necessary [43]. Despite promising results in vitro and in vivo, the antitumor effect of retrovirus mediated HSV-TK gene therapy in clinical trials remains insufficient due to very low transfection efficiency. In support of this, Sandmair et al. reported a Phase I clinical trial of 21 patients diagnosed with primary or recurrent GBM who were treated with replication-defective retrovirus or adenovirus. The results of this study showed that the median survival of the adenovirus mediated HSV-TK/GCV gene therapy group was significantly longer than the retrovirus mediated group [22]. Germano et al. also reported the safety of replication-defective adenoviral-mediated HSV-TK gene therapy in a Phase I trial, where the average survival of the treatment group was 112.3 weeks and one patient survived as long as 248 weeks from diagnosis. Collectively these trials indicate that using adenovirus to deliver the HSV-TK gene may be better in contrast to retroviral vectors [21]. At least $10 \%$ transfection efficiency is needed in order to obtain a significant reduction in tumor volume based on the results of the rat glioma xenograft experiments [44]. Clinical trials utilizing adenoviral delivery suicide gene therapy for glioma are currently underway (Table 1).

Suicide gene therapy using cytosine deaminase/5fluorocytosine (CD/5-FC) has been an extensively studied form of anti-glioma gene therapy [17]. CD is a microbial or a yeast enzyme capable of converting an effective antifungal drug, 5-FC, to the highly toxic anti-cancer compound 5-fluorouracil (5-FU) $[45,46]$. Since CD is absent in mammalian cells, 5-FC has minimal human toxicity. The toxic effects of 5-FU are mediated by the conversion of 5-FU to 5-FU triphosphate which interferes with 
Table 1 Ongoing clinical trials for gene therapy of GBM

\begin{tabular}{|c|c|c|c|c|c|c|c|}
\hline $\begin{array}{c}\text { Type of } \\
\text { gene therapy }\end{array}$ & Phase & Vector & Gene & Prodrug & Nation & ID & Title \\
\hline Suicide & Pilot & NSC & $C D$ & $5-\mathrm{FC}$ & USA & NCT01172964 & $\begin{array}{l}\text { A Pilot Feasibility Study of Oral 5-Fluorocytosine } \\
\text { and Genetically-Modified Neural Stem Cells } \\
\text { Expressing E. Coli Cytosine Deaminase for } \\
\text { Treatment of Recurrent High Grade Gliomas }\end{array}$ \\
\hline Suicide & I & AV & HSV-TK & Valacyclovir & USA & NCT00751270 & $\begin{array}{l}\text { Phase } 1 \mathrm{~b} \text { Study of AdV-tk + Valacyclovir Combined } \\
\text { With Radiation Therapy for Malignant Gliomas }\end{array}$ \\
\hline \multirow{2}{*}{$\begin{array}{c}\text { Suicide/ } \\
\text { immune-mediated }\end{array}$} & \multirow{2}{*}{1} & AV & HSV-TK & Valacyclovir & \multirow{2}{*}{ USA } & \multirow{2}{*}{ NCT01811992 } & \multirow{2}{*}{$\begin{array}{l}\text { Combined Cytotoxic and Immune-Stimulatory } \\
\text { Therapy for Glioma }\end{array}$} \\
\hline & & AV & Flt3L & - & & & \\
\hline Suicide & I & $\begin{array}{c}\text { RV } \\
\text { (Toca 511) }\end{array}$ & $C D$ & $5-F C$ & USA & NCT01470794 & $\begin{array}{l}\text { Study of a Retroviral Replicating Vector to Treat } \\
\text { Patients Undergoing Surgery for a Recurrent } \\
\text { Malignant Brain Tumor }\end{array}$ \\
\hline Suicide & I & $\begin{array}{c}\text { RV } \\
\text { (Toca 511) }\end{array}$ & $C D$ & $5-F C$ & USA & NCT01985256 & $\begin{array}{l}\text { Study of a Retroviral Replicating Vector Given } \\
\text { Intravenously to Patients Undergoing Surgery for } \\
\text { Recurrent Brain Tumor }\end{array}$ \\
\hline Suicide & 1 & AV & HSV-TK & Valacyclovir & USA & NCT00634231 & $\begin{array}{l}\text { A Phase I Study of AdV-tk + Prodrug Therapy in } \\
\text { Combination With Radiation Therapy for Pediatric } \\
\text { Brain Tumors }\end{array}$ \\
\hline Suicide & |/II & $\begin{array}{c}\text { RV } \\
\text { (Toca 511) }\end{array}$ & $C D$ & $5-F C$ & USA & NCT01156584 & $\begin{array}{l}\text { A Study of a Retroviral Replicating Vector } \\
\text { Administered to Subjects With Recurrent Malignant } \\
\text { Glioma }\end{array}$ \\
\hline Suicide & $\|$ & AV & HSV-TK & Valacyclovir & USA & NCT00589875 & $\begin{array}{l}\text { Phase 2a Study of AdV-tk With Standard Radiation } \\
\text { Therapy for Malignant Glioma (BrTK02) }\end{array}$ \\
\hline Oncolytic & I & $\begin{array}{c}\text { HSV } \\
\text { (HSV1716) }\end{array}$ & - & - & USA & NCT02031965 & $\begin{array}{l}\text { Oncolytic HSV-1716 in Treating Younger Patients } \\
\text { With Refractory or Recurrent High Grade Glioma } \\
\text { That Can Be Removed By Surgery }\end{array}$ \\
\hline Oncolytic & 1 & MV & CEA & - & USA & NCT00390299 & $\begin{array}{l}\text { Viral Therapy in Treating Patients With Recurrent } \\
\text { Glioblastoma Multiforme }\end{array}$ \\
\hline Oncolytic & 1 & $\begin{array}{c}\text { AV } \\
(\mathrm{DNX}-2401) \\
\end{array}$ & - & - & Spain & NCT01956734 & $\begin{array}{l}\text { Virus DNX2401 and Temozolomide in Recurrent } \\
\text { Glioblastoma }\end{array}$ \\
\hline Oncolytic & I & $\begin{array}{c}\text { PoV } \\
\text { (PVS-RIPO) }\end{array}$ & - & - & USA & NCT01491893 & $\begin{array}{l}\text { Poliovirus Vaccine for Recurrent Glioblastoma } \\
\text { Multiforme (GBM) }\end{array}$ \\
\hline Oncolytic & I & $\begin{array}{c}\text { AV } \\
(\mathrm{DNX}-2401)\end{array}$ & - & - & USA & NCT00805376 & $\begin{array}{l}\text { DNX-2401 (Formerly Known as Delta-24-RGD-4C) } \\
\text { for Recurrent Malignant Gliomas }\end{array}$ \\
\hline Oncolytic & $|/| \mid$ & $\begin{array}{c}\text { HSV } \\
\text { (G47Delta) }\end{array}$ & LacZ & - & Japan & $\begin{array}{l}\text { JPRN- } \\
\text { UMIN000002661 }\end{array}$ & $\begin{array}{l}\text { A Clinical Study of a Replication-Competent, } \\
\text { Recombinant Herpes Simplex Virus Type } 1 \text { (G47delta) } \\
\text { in Patients With Progressive Glioblastoma } \\
\end{array}$ \\
\hline Oncolytic & $|/| \mid$ & $\begin{array}{c}\mathrm{PaV} \\
(\mathrm{H}-1 \mathrm{PV})\end{array}$ & - & - & Germany & NCT01301430 & $\begin{array}{l}\text { Parvovirus H-1 (ParvOryx) in Patients With Progressive } \\
\text { Primary or Recurrent Glioblastoma Multiforme }\end{array}$ \\
\hline Oncolytic & |/II & $\begin{array}{c}\mathrm{AV} \\
\text { (Delta24-RGD) }\end{array}$ & - & - & Netherlands & NCT01582516 & $\begin{array}{l}\text { Safety Study of Replication-competent Adenovirus } \\
\text { (Delta-24-rgd) in Patients With Recurrent Glioblastoma }\end{array}$ \\
\hline Oncolytic & |/II & $\begin{array}{c}\text { AV } \\
\text { (Delta24-RGD) }\end{array}$ & - & - & Netherlands & $\begin{array}{l}\text { EUCTR2007- } \\
001104-21-\mathrm{NL}\end{array}$ & $\begin{array}{l}\text { A Phase I/II Trial of a Conditionally Replication- } \\
\text { Competent Adenovirus (delta-24-rgd) Administered } \\
\text { Convection Enhaced Delivery in Patients With } \\
\text { Recurrent Glioblastoma Multiforme }\end{array}$ \\
\hline *Suicide & I & NSC & $C D$ & $5-F C$ & USA & NCT02015819 & $\begin{array}{l}\text { Genetically Modified Neural Stem Cells, Flucytosine, } \\
\text { and Leucovorin Calcium in Treating Patients With } \\
\text { Recurrent High-Grade Gliomas }\end{array}$ \\
\hline${ }^{*}$ Oncolytic & $|/| \mid$ & NDV & - & - & Israel & NCT01174537 & $\begin{array}{l}\text { New Castle Disease Virus (NDV) in Glioblastoma } \\
\text { Multiforme (GBM), Sarcoma and Neuroblastoma }\end{array}$ \\
\hline $\begin{array}{l}\text { *Oncolytic/ } \\
\text { immune-mediated }\end{array}$ & I & HSV (M032) & $\mathrm{IL}-2$ & - & USA & NCT02062827 & Genetically Engineered HSV-1 Phase 1 Study \\
\hline
\end{tabular}


RNA processing after incorporation into RNA; and to 5-fluoro-2'-deoxyuridine 5' -monophosphate, which irreversibly inhibits thymidylate synthase, and blocks DNA synthesis (Figure 1) [19]. Similar to HSV-TK gene therapy, apoptosis underlies the cytotoxic mechanism of CD/5-FC gene therapy [30,47]. 5-FU is a small molecule that can diffuse in and out of transduced and neighboring cells, resulting in significant bystander effects which do not require cell-cell contact and functional gap junctions $[48,49]$. In comparison to HSV-TK gene therapy, $\mathrm{CD} / 5$-FC gene therapy demonstrated a greater anti-tumor effect when observed in a colorectal xenograft tumor model where only $4 \%$ of tumor cells are transduced [50]. Dong et al. reported that replicationdeficient adenovirus vectors carrying the $C D$ gene and subsequent administration of 5-FC resulted in significant prolonged survival in glioma-bearing rats [51]. Several attempts have been made to increase the efficacy of CD/ 5-FC gene therapy. Adachi et al. reported that a second enzyme, uracil phosphoribosyltransferase (UPRT), which is absent from mammalian cells, directly converts 5 -FU into 5-fluorouridine monophosphate which enhances the cytotoxicity of $\mathrm{CD} / 5$-FC gene therapy in an experimental malignant brain tumor, suggesting that co-expression of $C D$ and UPRT genes have synergistic anti-tumor effects [52]. In addition, the combination of CD/5-FC and UPRT gene therapy also enhances conventional radiotherapy in an animal model of glioma [53]. Further enhancement of cytotoxicity is accomplished by using replication-defective adenoviral vector encoding a mutant bacterial $C D$ gene with increased affinity for 5-FC [19]. The combination of this recombinant $C D$ gene with ionizing radiotherapy has shown significant tumor cell killing and inhibition of tumor growth in glioma xenograft models [19]. Recently, a second generation non-lytic retroviral replicating vector (Toca 511) demonstrated stable delivery of CD resulting in significant survival benefit without treatment related toxicity in a mouse glioma model [54]. Furthermore, synergistic therapeutic efficacy of TMZ, which is the most frequently used treatment for patients with GBM, was observed in combination with Toca 511 with subsequent administration of 5-FC resulting in a survival advantage in mice bearing TMZ-sensitive glioma [55].

A novel approach to suicide gene therapy involves the use of genetically engineered neural stem cells as a vector. Neural stem cells have the ability of continuous proliferation and differentiation into neuronal or glial cells [56-58]. One of the great advantages of using neural stem cells as a vector for GBM therapy is their invasive capability directed towards tumor cells, even when injected adjacent to the tumor $[59,60]$. Genetically engineered neural stem cells have been successfully used to deliver $\mathrm{CD}$ and HSV/TK gene products into GBM $[59,61,62]$.
$\mathrm{CD} / 5$-FC gene therapy has reached clinical trials and Toca 511 or genetically modified neural stem cells used as vectors are currently under investigation in patients with recurrent high grade glioma [54,55] (Table 1). An additional type of stem cell vector is the mesenchymal stem cell. Mesenchymal stem cells are non-hematopoietic, multipotent stem cells. In comparison to neural stem cells, mesenchymal stem cells have advantages because they are easily acquired from patient tissues such as bone marrow, adipose tissue, muscle tissue, and peripheral blood stream $[27,63]$. Their intrinsic ability to migrate to the site of injury and inflammation allows them to invade into tumors [64]. Owing to this strong homing behavior, mesenchymal cells have been used as a vector for gene therapy against glioma [65]. Some suicide gene therapies have employed mesenchymal stem cells as a vector, including HSV/TK, $\mathrm{CD}$, and HSV/TK combined with connexin-43 to enhance bystander effect [66-68].

\section{Oncolytic gene therapy}

A substantial focus in viral vector development has been the creation of genetically engineered adenoviruses and retroviruses. However, researchers are confronted with the limitations of their low efficiency for distribution, delivery to target cells and difficulties in achieving prolonged efficacy. Oncolytic gene therapy employs replicationcompetent viral vectors in order to increase the toxicity and efficiency against the tumor. Oncolytic viral vectors have the ability to selectively replicate in target tumor cells, and then to release viral particles and to spread to new adjacent progeny cells as the host cell is lysed (Figure 2A). Although, in some studies, immunosuppression has been shown to improve viral oncolytic effect, there is increasing evidence that oncolytic gene therapy will ultimately require an antitumor immune response as well as disruption of the tumor microenvironment such as inhibition of angiogenesis [10,69-74]. The transduction efficiency of replication-competent viral vectors in tumors is significantly higher than that of replicationdeficient viral vectors [17]. Oncolytic HSV, conditionally replicating adenovirus, measles virus (MV), poliovirus (PoV), Newcastle disease virus, parvovirus (H1-PV), and reovirus have all been employed and clinically tested in oncolytic gene therapy strategies for GBM (Table 1) $[17,27,75]$. Below, we describe the strategies for antiglioma oncolytic viral therapy.

HSV-1 is an enveloped double strand DNA virus with neurotropic properties capable of replication in dividing and non-dividing cells $[13,76,77]$. Wild type HSV-1 may either proceed to a lytic life cycle or stay in an intranuclear episome which is never integrated into the host genome. An advantage of an HSV-1 mediated approach is the documented sensitivity to acyclovir and GCV, thus adding to its safety profile. G207 is a conditionally replicating HSV 

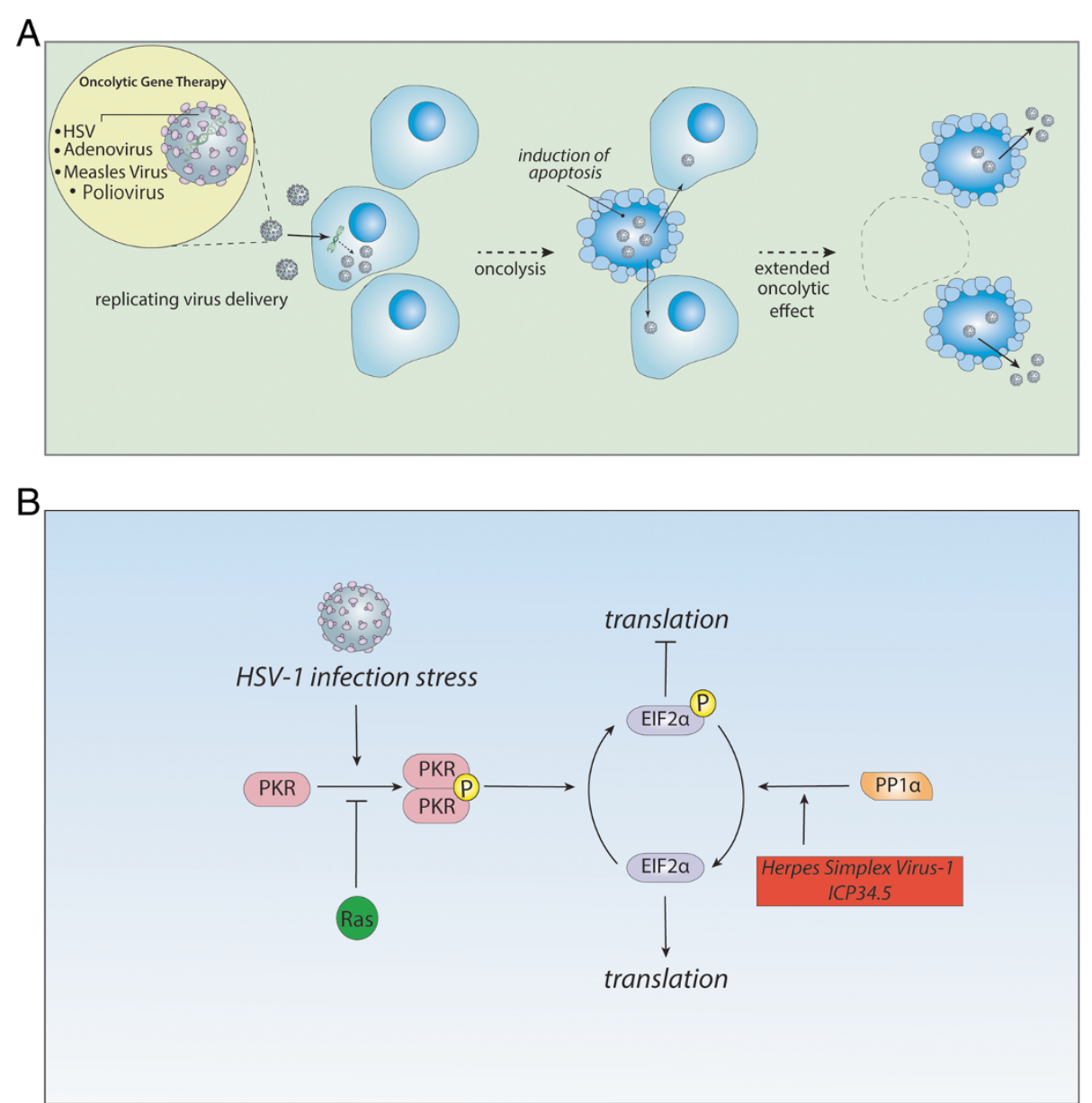

Figure 2 Strategy and mechanism for oncolytic gene therapy. (A); Oncolytic gene therapy employs replication-competent virus vectors capable of selective replication in target tumor cells. Spreading to new adjacent progeny cells occurs as the host cell is lysed and progeny virus is released. (B); Most viruses can replicate poorly in normal cells by a defense mechanism as follows. In response to viral infection, Protein Kinase $\mathrm{R}(\mathrm{PKR})$ in the host cells shut off protein synthesis by which PKR dimerizes and is inactivated by autophosphorylation resulting in the conversion of eukaryotic initiation factor-2 alpha (EIF-2a) into its inactive state following phosphorylation, which is required for translation initiation. Consequently, translation is arrested in the infected host cells as an anti-viral protective mechanism. However, the ICP34.5 in HSV-1 can overcome this defense by recruiting protein phosphatase-1a to dephosphorylate EIF-2a allowing protein synthesis to proceed. Therefore, when a deletion of $y 34.5$ gene is engineered, the HSV-1 mutant can no longer successfully proliferate in non-replicating cells. HSV-1 lacking ICP34.5 activity can only infect cells with defective PKR pathway. In tumor cells, PKR autophosphorylation is blocked due to Ras activation, permitting replication of viruses lacking the $\gamma 34.5$ gene in tumor cells with hyper-activated Ras.

mutant vector that is a genetically engineered HSV-1 (F) strain lacking the genes necessary for viral replication in normal cells. G207 has a deletion in both copies of $\gamma 34.5$ gene which encodes for the protein synthesis promoting factor infected cell protein (ICP) 34.5. In addition, the Unique Long (UL) 39 gene is inactivated by an insertion of the $L a c Z$ reporter gene into the region of the UL39 gene encoding ICP6, thereby disrupting the large subunit of the enzyme ribonucleotide reductase (RR) [78]. The enzyme, $\mathrm{RR}$, is crucial for nucleotide synthesis after infection of post-mitotic cells such as neurons $[79,80]$. Oncolytic HSV virus which has an impaired RR cannot replicate in nondividing cells but can replicate only in dividing cells, which is due to the mitotic cells providing cellular $R R$ and circumventing the need for viral RR. Therefore, oncolytic viruses which have mutation in $U L 39$ gene can achieve effective lytic activity only in dividing cells such as malignant glioma. However, it was estimated that only $5-15 \%$ of malignant glioma cells are in mitotic phase at any moment in time, meaning that the majority of malignant glioma cells can escape this type of oncolytic gene therapy [81,82]. However, the ICP6-defective HSV retains significant replicative ability in p16-deficient cells independent of cell cycle status [81]. Therefore, G207 can target nondividing cells with p16 deletion or inactivation [81].

An added safety advantage of the RR-deficient virus, G207, is modest hypersensitivity to anti-viral agents such as acyclovir and GCV [83]. The bacterial reporter gene 
$L a c Z$ is a useful histological marker to monitor the distribution of viral infection within the target tissues [84]. The neurovirulence gene, $\gamma 34.5$ is crucial to overcome host cell defense mechanisms after infection. During viral infection, a stress response is initiated by the host cells. Protein Kinase R (PKR) activation arrests translation in the infected host cells in order to induce an anti-viral protective mechanism by phosphorylating and inactivating eukaryotic initiation factor-2 alpha (EIF-2 $\alpha$ ) which is required for the initiation of translation. However, ICP34.5 in HSV-1 recruits protein phosphatase- $1 \alpha$ to dephosphorylate EIF-2 $\alpha$ and promote protein synthesis (Figure 2B) [85]. HSV-1 lacking ICP34.5 activity can only infect cells with a defective PKR pathway [86]. In tumor cells, PKR autophosphorylation is blocked due to Ras activation; therefore it allows selective replication of the viruses lacking the $\gamma 34.5$ gene in tumor cells with hyper-activated Ras (Figure 2B) [84,87-89]. UL39 gene encoding RR is crucial for virus replication given its functional role in catalyzing the formation of ribonucleotides, which are essential to nucleotide synthesis from ribonucleotides. Therefore RR is critical for viral DNA synthesis. Virus replication depends on RR in normal non-dividing cells; therefore the lack of viral RR expression in the G207 is compensated for by the tumor cells with high RR activity which results in highly specific targeting of tumor cells.

Preclinical studies using G207 demonstrated decreased tumor growth in experimental gliomas and a high safety profile [78,90-93]. Based on these results, G207 mediated oncolytic therapy was taken to clinical trials to begin evaluating its efficacy in anti-glioma therapy. Markert et al. reported a Phase I clinical trial using G207 in 2000 [94]. In total, 21 patients with progressive malignant glioma were enrolled. The trial demonstrated no treatmentrelated toxicity or serious adverse events; and no evidence of HSV encephalitis was observed. A positive therapeutic response was identified in eight patients, and one patient survived 5.5 years after the treatment. A maximally tolerated dose could not be determined because there were no dose-limiting toxicity even with inoculation of $3 \times 10^{9}$ Plaque-Forming Units (PFUs) [94]. In a Phase Ib study, six patients with recurrent glioma received G207 inoculation totaling $1.15 \times 10^{9}$ PFUs both prior to surgery and post operatively. The virus was injected either directly into the tumor or into the resected tumor cavity using a stereotactically guided catheter. Three of the patients showed subsequent improvement and the overall survival was greater than six months. In this study, there was no evidence of virus-related toxicities and G207 gene therapy was shown to have an excellent safety profile for repeated dose delivery as well as direct injection into the resected tumor cavity [95].

Another genetically engineered HSV-1 mutant is HSV1716, derived from the parent wild-type strain
HSV-1 17+ [96]. This conditionally replicative mutant virus has a $759 \mathrm{bp}$ deletion in both copies of $\gamma 34.5$ gene, inactivating the ICP34.5 protein and the intact UL39 gene. HSV1716 is capable of replication in dividing cells but not differentiated cells, conveying tumor cell selectivity similar to G207. In 1994, Valyi-Nagy et al. demonstrated that HSV1716 was nonvirulent in severe combined immunodeficiency mice making it a promising candidate for oncolytic gene therapy [97]. Moreover, the studies in animal models supported pursuing HSV1716 as a potential novel treatment strategy for malignant brain tumors [98-100]. The promising safety and efficacy profiles allowed HSV1716 to be tested for anti-glioma therapy in humans. As with G207, the safety and toxicity of HSV1716 administration in patients was first demonstrated in a Phase I clinical trial consisting of nine patients with recurrent glioma that received stereotactic intratumoral injections. Prior to the start of therapy, all patients had undergone surgery and radiotherapy and six patients received chemotherapy. Four patients remained alive for 14-24 months after the virus administration. None of the patients demonstrated signs of encephalitis following treatment, and there was no need to use anti-herpetic medication. It was remarkable that no major neurological manifestation was noted. The treatment decelerated tumor growth and increased the survival to three years in one patient and to four years in two patients. In this trial, a dose escalation study was also carried out with the initial doses of $1 \times 10^{3}$ to $1 \times$ $10^{5}$ PFUs. A maximum tolerated dose was not determined because the highest dose used in this study showed no adverse effects [101].

In a subsequent Phase Ib trial, Papanastassiou et al. demonstrated replication activity of HSV1716 within the tumors. All patients enrolled in this trial were inoculated with $1 \times 10^{5}$ PFUs intratumorally, and then underwent tumor resection four to nine days after injection. The resected tumors were analyzed for viral replication activity. While no treatment related toxicity was observed, there was evidence of viral replication upon histological examination [102]. A third clinical study was reported by Harrow in 2004 [103]. In this study, 12 patients with recurrent or newly diagnosed GBM underwent surgical resection. HSV1716 was injected into multiple sites around the resection cavity and none of the patients showed viral injection-related toxicity. Three patients demonstrated clinically stable disease and increased survival following surgery and viral injection at 15, 18, and 22 months [103]. HSV1716 has also been clinically used for advanced melanoma $[10,104]$. In three patients receiving multiple intranodular injections, immunohistochemical staining of injected nodules revealed evidence of virus replication confined to tumour cells without toxic effects [105]. Taken together, these studies show that 
HSV1716 has been successfully used in clinical trials for glioma therapy as well as other types of cancer. However, one drawback of these models is the required deletion of $\gamma 34.5$ genes which reduces the viral replication ability, and limits its efficacy [106].

Oncolytic HSVs which have deletions in both copies of $\gamma 34.5$ genes have limited or no replication in GSCs [107]. G47Delta is the new generation of oncolytic HSV. In order to restore GSC sensitivity, G47Delta has an additional deletion of the gene encoding ICP47 resulting in enhanced major histocompatibility complex (MHC) class I antigen presentation and enhanced immune response [107,108]. In addition, this deletion causes promoter shift for the unique short 11 gene which blocks the effect of interferons and consequently to increase virus replication in tumor cells [108,109]. G47Delta is being examined in pre-clinical models and preparing to proceed to clinical trials [108,110-112]. A Phase I/II clinical trial using G47Delta which further enhances specificity and safety is currently underway evaluating the efficacy and safety for recurrent or progressive GBM (Table 1).

AV are nonenveloped viruses with double strand DNA capable of infecting both proliferating and quiescent cells. $\mathrm{AV}$ vectors enter central nervous system (CNS) cells by receptor-mediated endocytosis; however, they are not integrated into cellular DNA, but exist as episomes in which AV's DNA is transcribed and translated using the intrinsic cellular machinery [113]. Given that AV's are not inserted into the host genome, there is minimal risk of insertional mutagenesis. Two commonly investigated conditionally replicating AVs in glioma are ONYX-015 (also known as d11520) and Ad5Delta24, both of which target cells with impaired signaling pathways [17,27].

ONYX-015 has a deletion in the $55 \mathrm{kD}$ protein early region $1 \mathrm{~B}-55 \mathrm{kD}$ (E1B-55kD) which conveys a selective phenotype to it [114]. E1B-55kD normally binds and inactivates the tumor suppressor p53 preventing the induction of p53 apoptosis in the infected cell before the virus cycle is complete. Consequently, the cells with functional p53 protein cannot assist viral replication without E1B-55kD. The absence of E1B-55kD results in selective replication in p53-deficient tumor cells [114-116]. An important consideration is that some studies have identified that there are additional beneficial mechanisms that may provide oncolytic activity of ONYX-015 in gliomas which are p53-independent, and may even be increased in p53 intact glioma cells [117-120]. Preclinical studies of ONYX015 in human malignant glioma xenografts derived from primary tumors demonstrated a high anti-tumor activity and widespread intratumoral replication in p53 wild-type tumors as well as p53-mutant tumors [117]. Furthermore, the efficacy of oncolytic therapy of the virus was enhanced by radiation therapy [121]. ONYX-015 is a promising agent for further anti-glioma research in animal model studies, and ONYX-015 needs to be tested in clinical trials for malignant glioma [117]. The initial Phase I dose-escalation clinical study in brain tumors was conducted in 24 patients with recurrent malignant glioma who were subdivided into four groups of six patients. Each patient received ONYX-015 at a dose from $1 \times 10^{7}$ PFUs to $1 \times 10^{10}$ PFUs injected into 10 different sites within the tumor bed cavity following surgical resection. None of the patients showed serious adverse effects related to ONYX-015; however, the maximum tolerated dose was not reached, even at the highest dose of $1 \times$ $10^{10}$ PFUs. The median time to progression and the median survival time were 46 days and 6.2 months, respectively. Despite ONYX-015's promising safety profile, there was no observable significant therapeutic benefit [122]. ONYX-015 was also used in clinical trials for other types of cancer such as squamous cell carcinoma and hepatobiliary carcinoma [10]. In contrast to the clinical trial for glioma, they showed anticancer effect without significant adverse effects [10,123-125]. These results suggest that ONYX-015 could be applied more effectively to patients with an earlier stage of GBM.

The Ad5Delta24 has a 24 bp deletion in the viral protein early region $1 \mathrm{~A}$. This deletion inhibits virus function by interfering with the retinoblastoma $(\mathrm{Rb})$ protein. Normally, phosphorylated $\mathrm{Rb}$ inhibits cell proliferation by binding and inactivating the transcription factor E2F. Infected cells with wild-type AV are transformed by inhibiting Rb-hypoP (hypo-phosphorylated form of $\mathrm{Rb}$ ) in the proliferative phase of the cell cycle (G1 to $S$ cell phase). $\mathrm{Rb}$ is a tumor suppressor protein that functions in a pathway that is commonly altered in gliomas [126,127]. In this manner, Ad5Delta24 can selectively replicate in glioma cells with an impaired $\mathrm{Rb}$ pathway [128]. Preclinical studies using the Ad5Delta24 demonstrated significant growth inhibition of glioma xenografts in nude mice. However, normal fibroblasts or cancer cells with intact $\mathrm{Rb}$ activity were refractory to the viral therapy [128]. The Ad5Delta24 was further genetically modified by the insertion of the integrin-binding Arg-Gly-Asp (RGD) motif into the fiber knob domain of the viral fiber protein, enabling anchoring to integrins to enhance viral tropisms (Ad5Delta24-RGD) [129]. Preclinical studies using this vector with malignant glioma cell lines successfully demonstrated that Ad5Delta24-RGD enhanced the specific targeting of the tumor cells and increased the oncolytic efficacy against glioma. Furthermore, the survival of mice harboring glioma xenografts that received an intratumoral injection of Ad5Delta24-RGD was improved in comparison to the mice that received Ad5Delta24 control vector [130]. An additional preclinical study in glioma xenografts demonstrated that the oncolytic activity of Ad5Delta24RGD was enhanced by irradiation [131]. A Phase I and I/II clinical trial using Ad5Delta24-RGD (DNX-2401) is 
currently underway evaluating efficacy for recurrent malignant glioma (Table 1) $[17,27,132]$.

MV, well-known as a human pathogen, is a singlestranded, enveloped RNA virus belonging to the family Paramyxoviridae. MV is known to be neurotropic and rarely causes encephalitis. MV's entry into cells requires attachment of the hemagglutinin envelope glycoprotein $\mathrm{H}$ to its cellular receptors such as CD46 and Signaling Lymphocyte Activating Molecule followed by fusion with the cell membrane through the envelope fusion glycoprotein F. These two glycoproteins play an important role for oncolytic specificity and efficacy. Mutations in the $\mathrm{H}$ protein of the attenuated MV, known as the Edmonston strain (MV-Edm), has a high affinity for cellular CD46 receptors which are ubiquitously overexpressed in a wide range of tumors [133-136]. The F protein is responsible for membrane fusion and induces the formation of multinucleated syncytia followed by apoptosis [137]. The MV-Edm was genetically engineered to express the circulating carcinogenic embryonic antigen (CEA) in order to monitor the viral activity and maintenance of MV $[138,139]$. This MVCEA demonstrated favorable anti-tumor activity and safety profile in animal models including a primary tumor GBM xenograft model [75]. Based on these results, a Phase I clinical trial of the MV-CEA strain in patients with GBM is currently underway (Table 1 ) [17,27]. MV variants have been engineered to express either interleukin (IL)-13 as a ligand to the GBM specific receptor IL-13R $\alpha 2$ or a single-chain antibody against the vIII deletion variant of EGFR [140-142]. These MV variants have the capability of targeting specific proteins expressed on glioma cells thereby increasing their oncolytic activity and specificity.

$\mathrm{PoV}$ is a positive-sense, non-enveloped RNA virus with natural neurotropism belonging to the Picornaviridae family and is the virus responsible for human poliomyelitis [136]. Viral neurotropism is attributed to the viral entry receptor CD155 (also known as the poliovirus receptor) which has been ectopically expressed and evaluated in malignant glioma cells [143-145]. Viral neuropathogenicity is attributed to an internal ribosomal entry site (IRES), located in the $5^{\prime}$ untranslated region of the poliovirus genome, which mediates viral protein translation [146]. In order to eliminate the neurotoxicity, Gromeier et al. created a recombinant intergeneric virus by replacing the PoV IRES sequence with a nonpathogenic version from human rhinovirus type 2 [147]. This recombinant PoV, PVS-RIPO, is derived from the Sabin polio vaccine, which has greatly diminished viral proliferation in normal neuron cells while retaining significant lytic growth in malignant glioma cells [143]. When delivered directly into the spinal cord, PVS-RIPO significantly diminished poliomyelitis-like neurotoxicity in both mice transgenic for the CD155 receptor and nonhuman primates [143,144]. Preclinical studies of PVS-RIPO demonstrated significant biologic effects. Treatment of athymic mice bearing intracerebral glioma xenografts with PVS-RIPO attenuated tumor progression and lead to tumor elimination [143]. Based on these results, a Phase I clinical trial using PV-RIPO is currently underway for application in recurrent malignant glioma (Table 1).

Stem cells used as carriers of oncolytic viruses have become a promising approach because of their natural tropism and ability to infiltrate solid tumors so that they can deliver the viruses at further distance within large lesions [148]. There have been several examples demonstrating the usefulness of using stem cells (neural stem cells or mesenchymal stem cells) to deliver conditionally replicating HSV and AV in preclinical studies [149-152]. As expected, the reach of viral delivery was strongly enhanced by using neural stem cells. Mesenchymal stem cells carrying conditionally replicating AV has demonstrated that the stem cell vector can suppress the immune response against the virus, which makes it possible to prolong viral activity [152]. Intra-arterial delivery of mesenchymal stem cells carrying Ad5Delta24-RGD selectively localized to human gliomas and were capable of delivering and releasing Ad5Delta24-RGD into the tumor, resulting in improved survival and tumor eradication in glioma xenograft mouse models [153]. These results suggest that stem cells carrying oncolytic virus may be administered systemically and demonstrate viral delivery more efficiently.

\section{Cytokine mediated gene therapy}

The underlying principle of cytokine mediated gene therapy involves tumor-selective gene transfer and in situ expression of various cytokine genes such as IL-2, $-4,-12$, and interferon (IFN) $\beta,-\gamma$ which can induce robust immune responses restricted to antigens specific to glioma cells $[17,37,77,154]$. Given that the CNS is relatively isolated from the systemic immune system, gliomas can effectively evade the host immune response [13,27]. Several physiological mechanisms unique to the CNS immune system include lack of antigen-presenting cells such as dendritic cells (DCs); lack of production of antiinflammatory mediators such as transforming growth factor (TGF)- $\beta$; weaker expression of major MHC class I and II; and the existence of BBB. These mechanisms play important roles to protect the CNS from immunological attack (Figure 3). Therefore, it is challenging to stimulate the immune system to develop an effective anti-tumor response against gliomas [69]. Indeed, various cytokines such as IFNs and IL have been used clinically for the treatment of cancer, including chronic myeloid leukemia, $\mathrm{T}$ cell and $\mathrm{B}$ cell lymphomas, melanoma, and renal carcinoma $[155,156]$. Several preclinical studies have demonstrated the feasibility of mobilizing the immune response against glioma cells. The susceptibility 


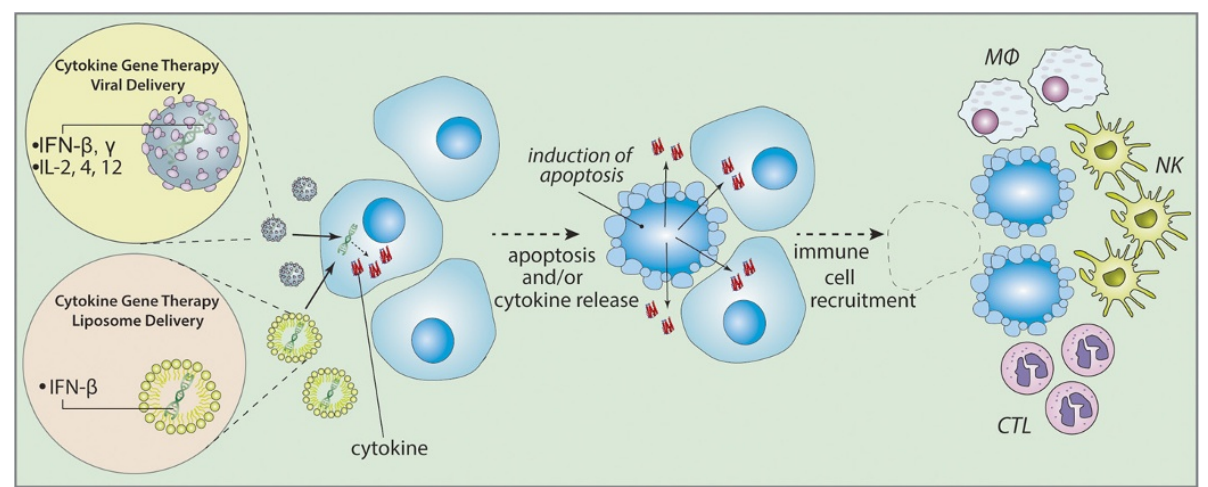

Figure 3 Strategy of cytokine mediated gene therapy. Cytokine mediated gene therapy involves tumor-selective gene transfer and in situ expression of various cytokine genes such as interleukin (IL) and interferon (IFN) capable of attracting immunocompetent cells such as macrophages $(\mathrm{M \Phi})$, natural killer cells (NK), and cytotoxic T lymphocytes $(\mathrm{CTL})$ inducing immune response.

of glioma stem cells to the cytotoxic effects of the immune system provide the basis for developing anti-glioma immune gene therapy based on immunomodulation. Melanoma cells infected with a viral vector carrying the gene for granulocyte-macrophage colony stimulating factor were injected subcutaneously in mouse. This cytokine generated a strong immune response against intracranial melanoma in the mouse model $[157,158]$. With regard to the treatment for glioma, using various types of vectors for cytokine gene delivery may allow local augmentation of immune response. Since then, a variety of cytokines such as interleukin and interferon gene therapies have been studied to activate and enhance the effectiveness of immune therapy against tumors.

IFN- $\beta$, type I interferon genes, are primarily produced by specialize antigen presenting cells such as DCs post viral infection [155]. IFN- $\beta$ is an immunostimulatory molecule inducing $\mathrm{MHC}$ class I expression, leading to an increase in cytotoxic $\mathrm{T}$ cells activity, enhancing the generation of $\mathrm{T}$ helper cells and activating natural killer (NK) cells, DCs, and inducing macrophage activity $[154,155,159,160]$. These immunomodulatory activities can lead to a robust anti-tumor immune response. Qin et al. reported a successful effect following IFN- $\beta$ gene delivery using a replication-deficient adenovirus under the control of a cytomegalovirus (CMV) promoter [160]. Direct injection of the IFN- $\beta$ gene with a replicationdeficient adenovirus demonstrated tumor regression in human xenografts including glioma, through the activation of NK cells. Survival was significantly prolonged in these mice [161]. Based on these results, an IFN- $\beta$ expressing replication-defective AV was used in Phase I clinical trials for recurrent malignant glioma. The 11 enrolled patients received stereotactic injection of the vector into the tumor and surrounding intact brain following resection. One out of 11 patients experienced treatment related dose-limiting toxicity. Tumor histopathological analysis revealed dose-related induction of apoptosis and necrosis [162].

The use of a different type of vector, cationic liposomes, was also used for IFN- $\beta$ gene transfer. Local administration of cationic liposomes containing the IFN- $\beta$ gene induced marked inhibition of tumor growth, NK cell activation, and prolonged survival of mice bearing human glioma xenografts $[163,164]$. In addition, cationic liposomes containing the IFN- $\beta$ gene induced cytotoxic T-cell immunity against mouse glioma cells and marked tumor growth inhibition by activation of the immune response in experimental gliomas $[165,166]$. Based on these results, this strategy reached a Phase I clinical trial for recurrent malignant glioma. There was no observable toxicity attributable directly to the use of liposome. Two patients with anaplastic astrocytoma experienced more than 50\% tumor reduction for at least 16 months [167]. Subsequent histological examination demonstrated a dramatic change in the tumor tissue including the presence of CD8 positive lymphocytes and marked macrophage infiltration as well as apoptosis and neovascularization [168]. The addition of IFN- $\beta$ to TMZ chemotherapy for patients with newly diagnosed GBM results in a more favorable outcome than standard therapy of TMZ alone $[155,169]$. Neural stem cells have also been used to deliver a combination of CD and IFN- $\beta$ together to enhance the bystander effect and the immune response against the glioma, demonstrating improved anti-tumor response compared to CD alone [24].

Similar to IFN- $\beta$, the type II interferon gene, IFN- $\gamma$, is also an immune stimulatory cytokine produced by NK cells, dendritic cells, and activated T-lymphocytes $[69,170]$. IFN- $\gamma$ inhibits the adhesion of malignant glioma cells in vitro and diminishes the invasive phenotype of glioma cells by reducing binding to extracellular matrix macromolecules [171]. Single-agent activity of IFN- $\gamma$ has appeared to be less effective than IFN- $\beta$ [154] and 
several attempts to focus on the use of combination regimens have been performed. The use of AVs expressing tumor necrosis factor (TNF)- $\alpha$ or IFN- $\gamma$ introduced into tumors enhanced infiltration of CD4 and CD8 positive $\mathrm{T}$ cells in addition to increasing expression of $\mathrm{MHC}$ class I and II on the tumor cells in a mouse glioma model. Intracranial administration of both vectors led to a statistically significant increase in survival of tumor bearing mice [172]. In addition, simultaneous delivery of IFN- $\gamma$ inducible protein 10 and TNF- $\alpha$, both potent immune-stimulatory cytokines, was attempted in a GBM mouse model using recombinant parvovirus [173]. The study demonstrated synergistic activity when using both vectors and complete regression of tumors generated from murine glioma cells that had been infected in vitro with both cytokines before implantation. Although IFN- $\gamma$ is thought to have anti-angiogenic properties, cytokinemediated immune stimulation was likely responsible for the therapeutic response $[173,174]$. IFNs have been the ideal cytokines to be applied clinically in a variety of human cancers $[154,155]$. However, the results of IFN treatment of most solid tumors have been generally disappointing $[175,176]$. The unsatisfactory performance of IFNs in cancer treatments has been in part attributed to the poor delivery of the protein to the tumor $[160,175]$. Nevertheless, some reports demonstrated that combination of cytokine gene therapy with conventional chemotherapy or other types of cytokines show a favorable outcome compared to single cytokine gene therapy $[155,169]$. In the future, combination gene therapy will likely become standard protocol for glioma therapy.

Viral-mediated delivery of single interleukins has not been as extensively investigated in GBM as in other cancers, but studies in this direction have definitely shown therapeutically relevant results [27]. In order to activate T-cells, a tumor cell must present tumor cell antigen in the context of MHC class I and simultaneously present the co-stimulatory antigen. Once the T-cell is activated, it up-regulates the functional high affinity IL-2 receptor and secretes IL-2 and -4 . The T cell proliferates in response to autocrine signals from IL-2 and IL-4 resulting in an anti-tumor effect [9]. On the other hand, IL-12 is produced by phagocytes, B cells and DCs following an encounter with infectious agents. IL-12 acts on T and NK cells by enhancing the generation and activity of cytotoxic lymphocytes and inducing the proliferation and production of cytokines. IL-12 is the major cytokine responsible for the differentiation of helper $\mathrm{T}$ cells, which are potent inducers of IFN- $\gamma$. IFN- $\gamma$, in turn, has a strong effect on the ability of phagocytes and DCs to produce IL$12[177,178]$. Consequently, IL-12 has a potent adjuvant activity in generating anti-cancer effects [177].

In a rat glioma model, recombinant vaccinia virus expressing the cytokines IL-2 or IL-12 resulted in tumor growth inhibition after intratumoral injection [179]. Combination gene therapies of IL-2 and IL-12 proved to be more effective in increasing the NK, Natural killer T, and Mac- $1^{+}$phagocytic cell populations in blood as well as increased IFN- $\gamma$, and TNF- $\alpha$ expression in tumors without significant toxicity. Non-replicating adenoviral-associated virus and replicating HSV have also been used to distribute IL-12 in experimental models of malignant gliomas [180-182] and the results showed a significant inhibition of tumor growth and a local immune reaction including increased IFN- $\gamma$ expression, microglial activation, and recruitment of $\mathrm{T}$ and NK lymphocytes (Figure 3). Colombo et al. reported using combined delivery of IL-2 with HSVTK for 12 patients with recurrent malignant glioma [183]. All patients received a stereotactic or open surgical intratumoral injection of retroviral vector-producing cells which express both the $H S V$-TK gene and $I L-2$ gene following by intravenous GCV. The 12-month progression-free survival rate and overall survival rates were $14 \%$ and $25 \%$, respectively. Although there was a marked increase of circulating IFN- $\gamma$, TNF- $\alpha$, IL- 2 , and IL-10, only minor adverse events were noted [183].

IL-4 is produced by Th2-type T lymphocytes, mast cells, and basophils [184]. IL-4 increases surface MHC class II antigen expression in B cells and stimulates the growth of both helper and cytotoxic $\mathrm{T}$ cells, including tumor infiltrating lymphocytes [185-187]. Therefore, IL-4 is thought to have a potent anti-tumor effect in vivo against various types of cancer by inducing an immune response [188-191]. Okada et al. demonstrated a synergistic effect using a retrovirally transduced $I L-4$ plus $H S V$-TK gene in a rat intracranial glioma model [192]. This resulted in a clinical trial using $I L-4 / H S V-T K$ gene-modified autologous glioma cells or fibroblasts [193]. Conditionally replicative oncolytic HSV carrying IL-12 gene therapy will start in Phase I clinical trial to determine the safety in patients with recurrent glioma (Table 1).

\section{Tumor suppressor gene therapy}

The aim of tumor suppressor gene therapy is to restore the function of a tumor suppressor gene lost or functionally inactivated in cancer cells (Figure 4). Commonly, they regulate diverse cellular activities including cell-cycle checkpoints, detection and repair of DNA damage, cell proliferation and apoptosis.

The tumor suppressor gene, P53 is located on chromosome 17p and encodes a 393 amino acid protein [194-196]. As the name "Guardian of the Genome" suggests, p53 plays a critical role in causing cell cycle arrest and apoptosis in response to a variety of cellular stress such as radiation exposure [197-200]. P53 directly contributes to DNA repair, and inhibition of angiogenesis [195,199]. The most wellcharacterized function of p53 is the inhibition of abnormal cell growth. Many factors contribute to the control of 


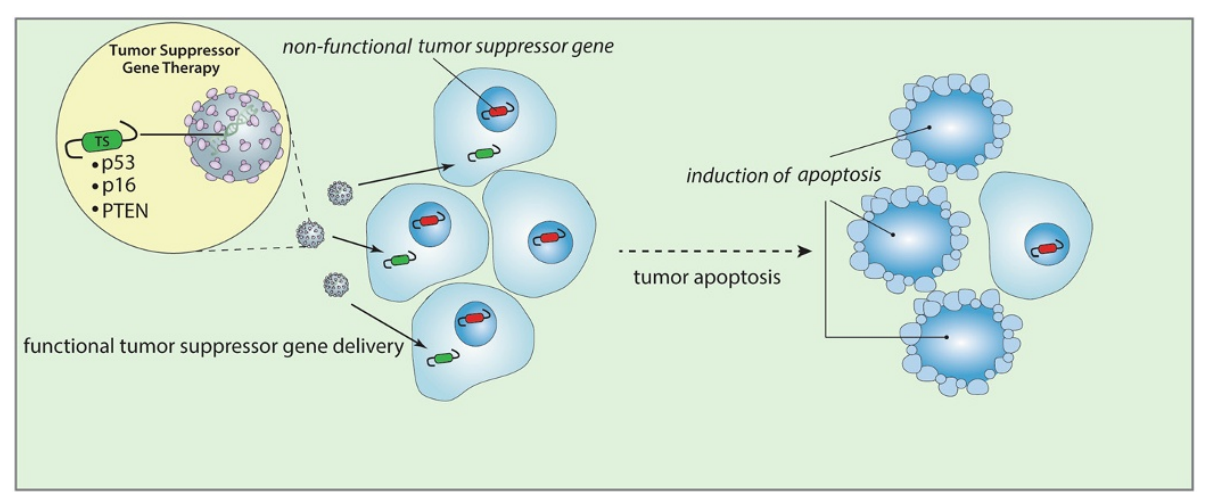

Figure 4 Strategy of tumor suppressor gene therapy. Tumor suppressor gene therapy aims to reprogram tumor cells by restoring the function of a tumor suppressor gene lost or functionally inactivated in cancer cells, subsequently inducing cell cycle arrest or apoptosis.

p53 activation and its downstream response which are crucial in the prevention of tumor development.

Inactivation of $\mathrm{p} 53$, which is one of the most commonly mutated tumor suppressor genes in glioma, plays a critical role in glioma progression [113,201]. Alteration of p53 is seen in approximately $50 \%$ of grade II and III glioma, $25-30 \%$ of primary GBM, and $60-70 \%$ of secondary GBM [202]. Tumor suppressor gene therapy using p53 in glioma was first tested by delivering this gene using a replication-deficient AV [27]. The most commonly used non-replicating adenoviral vector for $p 53$ gene transfer is the type $5 \mathrm{AV}$ in which the $\mathrm{E} 1$ region is replaced with the cDNA of the $p 53$ gene and is driven under the control of a CMV promoter (Ad5CMV-p53) [113,203-209]. Removal of the E1 region makes the virus replication-defective, reducing the possibility of widespread, uncontrolled, systemic infection. The CMV promoter is particularly active in human cells and significantly increases gene expression [113]. Restoration of the functionally intact TP53 gene induced robust apoptosis of the infected cells and inhibited cellular proliferation both in vitro and in vivo $[113,204,207]$. There was marked growth inhibition of implanted gliomas and significant prolongation of survival in preclinical models [203,208-210]. P53 gene therapy might also suppress angiogenesis of GBM [211]. Several studies have suggested that Ad5CMV-p53 may be most effective when combined with radiation and chemotherapy [205,206,212,213]. An additional in vitro study suggested that combined p53 transfection with other type of genes such as Fas Ligand, granulocytemacrophage colony-stimulating factor and B7-1 enhances apoptosis and inhibits cell growth [214,215].

Collectively, these preclinical results led to a Phase I clinical trial of Ad5CMV-p53 gene therapy in recurrent malignant glioma. Eligible patients underwent stereotactic injection of the virus pre- and post-resection through an implanted catheter. Immunohistochemical staining for p53 protein confirmed exogenous p53 expression within the nuclei of glioma cells and induced apoptosis in all specimens examined. One limitation was revealed when transduced cells were only found within a short distance from the injection site. In terms of outcome, the median progression free survival and overall survival were 13 and 43 weeks, respectively. Of note, one patient was alive more than three years after treatment without evidence of recurrence. The clinical toxicity was minimal without reaching maximum tolerable dose [216]. Limitations of p53 gene therapy are considered to be insufficient gene transfer, lack of bystander effect and tolerance arising from genetic heterogeneity of glioma $[27,217]$.

Another tumor suppressor gene therapy candidate is p16 ${ }^{\mathrm{INK} 4 \mathrm{~A}}$, which causes cell cycle arrest at the G1-S transition point by stabilizing the hypo-phosphorylated status of the $\mathrm{Rb}$ protein $[200,218]$. The over-expression of p16 gene using a recombinant replication-deficient adenovirus significantly reduced glioma cells invasion as a result of decreased activity of matrix metalloprotease-2 [218].

The third tumor suppressor gene therapy candidate is Phosphatase and Tensin Homologue (PTEN) which contains a central catalytic phosphatase core domain that negatively regulates PI3K by dephosphorylating from phosphatidylinositol-triphosphate to phosphatidylinositoldiphosphate [200]. Inactivation of PTEN is seen in $40 \%$ to $50 \%$ of all gliomas resulting in aberrant activation of PI3K activity and downstream signaling pathways [219]. Expression of PTEN in GBM cells caused tumor cell apoptosis and decrease glioma cell proliferation in vitro [220,221]. Furthermore, adenoviral PTEN expression demonstrated an anti-angiogenic response in preclinical study [221].

\section{Conclusion}

GBM remains one of the most frequent and most clinically challenging primary brain tumors encountered by neurosurgeons. Over the past decades, current standard treatments have evolved to include maximal surgical resection followed by adjuvant radiation and chemotherapy. 
Unfortunately, these therapies have yet to cure patients with GBM. However, several remarkable advances in the treatment of GBM have occurred. Surgery augmented with powerful imaging techniques is aimed at maximal resection of tumor tissue without causing new neurological deficits. Effective reduction of tumor mass can allow the patients to achieve a better overall survival. Stereotactic radiosurgery or radiotherapy that attempt to enhance the effect of other treatment modalities has been developed. In addition to current standard conventional chemotherapy for GBM, advancements in our understanding of the pathogenesis of GBM and the molecular aberrations in GBM has led to new era of exciting possibilities for the treatments of GBM.

In the last few decades, a considerable amount of research utilizing gene therapy for glioma has been published in in vitro and in animal models. Although most of these methods have demonstrated success in in vitro and in pre-clinical studies, a majority of patients in early clinical studies have ultimately failed to demonstrate significant survival for the treatment of GBM. This is partly because experimental therapies in early clinical study are usually applied to patients with recurrent or advanced GBM disease, who have often been treated with multiple treatment regimes, including radiation or chemotherapy (TMZ) or both. These patient tumors are likely already beyond a curable level and a modest response can be expected even with a well established therapy at the time of the trial and this likely contributes to the low success rate observed in clinical trials. For proper evaluation of efficacy, patients with earlier stages of GBM need to be enrolled in clinical studies.

A number of specific difficulties are associated with gene therapy for GBM including: limited transduction efficiency of the viral vectors; lack of a delivery system that bypasses the BBB; inability to distinguish tumor cells from normal cells; and the selective expression of a transgene in a therapeutically controlled manner (Table 2). The histological heterogeneity of the cell population within the tumor is considered to be another major impediment. The restricted intratumoral distribution of the viral vector still remains an issue for obtaining optimal clinical efficacy due to the infiltrative nature of GBM. Greater vector stability, as well as prolonged therapeutic transgene expression, might result in more efficacious treatment of GBM. Therefore, in order to improve gene therapy efficiency, new vectors should overcome the limited infiltration and transgene expression that occurs after administration. In addition to viral vectors, stem cells have been successfully used to deliver therapeutic gene products to primary and secondary invasive brain tumors. Theyhave demonstrated their usefulness in combined gene therapy such as suicide gene therapy and cytokine gene therapy. Another important property is the stem cell's ability to migrate toward infiltrative GBM tumors even when administered peripherally. Stem cells may become an important vector option in gene therapy for GBM.

Gene therapy alone will not likely provide a cure of GBM, at least not in the near future. Since GBM is a heterogeneous tumor, therapeutic blocking of one or two pathways may simply result in the activation of alternative pathways leading to continuous tumor progression. Therefore, simply replacing a single lost gene (i.e. tumor suppressor gene) never brings about success in treatment of GBM. However, gene therapy was able to demonstrate significant anti-cancer effects in other types of cancers including melanoma, hepatocellular carcinoma, and squamous cell carcinoma in head and neck, suggesting that gene therapy still has a great potential for inclusion in GBM treatment protocols. Furthermore, multiple options are now available, including more complex systems involving combination of suicide genes or oncolytic virotherapy with immunological or tumor suppressor genes, selectively replicating viruses, and non-viral vectors. It is likely that

Table 2 Comparison of gene therapy strategies for GBM

\begin{tabular}{|c|c|c|c|}
\hline Suicide gene therapy & Oncolytic gene therapy & Cytokine mediated gene therapy & Tumor suppressor gene therapy \\
\hline $\begin{array}{l}\text { - Synergistic therapeutic efficiency } \\
\text { of conventional treatment }\end{array}$ & $\begin{array}{l}\text { - Additional therapeutic } \\
\text { transgenes available }\end{array}$ & $\begin{array}{l}\text { - Local augmentation of the } \\
\text { immune response inside the brain }\end{array}$ & - Anti-angiogenesis effect \\
\hline - Bystander effect & - Selective toxicity & $\begin{array}{l}\text { - Combination therapy with other } \\
\text { types of gene therapy available }\end{array}$ & $\begin{array}{l}\text { - Synergistic therapeutic efficiency of } \\
\text { conventional or other of gene therapy }\end{array}$ \\
\hline - Selective cytotoxicity & $\begin{array}{l}\text { - Higher transduction } \\
\text { efficiency }\end{array}$ & $\begin{array}{l}\text { - Reduce tumor vascularization and } \\
\text { invasion }\end{array}$ & \\
\hline $\begin{array}{l}\Delta \text { Transduced cells may become } \\
\text { resistant to the prodrug }\end{array}$ & $\begin{array}{l}\boldsymbol{\Delta} \text { Suppression of virus by } \\
\text { host immune response }\end{array}$ & $\begin{array}{l}\boldsymbol{\Delta} \text { Lack of antigen presenting cells } \\
\text { inside the brain }\end{array}$ & $\begin{array}{l}\boldsymbol{\Delta} \text { Resistance from the inherent genetic } \\
\text { heterogeneity }\end{array}$ \\
\hline $\boldsymbol{\Delta}$ Low efficiency for distribution & $\begin{array}{l}\boldsymbol{\Delta} \text { Cerebral inflammation } \\
\text { and edema }\end{array}$ & $\boldsymbol{\Delta}$ CNS toxicity & $\boldsymbol{\Delta}$ Lack of bystander effect \\
\hline $\boldsymbol{\Delta}$ Low delivery to target cells & & $\begin{array}{l}\boldsymbol{\Delta} \text { Poor delivery of a gene to the } \\
\text { tumor }\end{array}$ & $\boldsymbol{\Delta}$ Poor gene transfer \\
\hline $\boldsymbol{\Delta}$ Limited prolonged efficacy & & & \\
\hline
\end{tabular}

$\bullet$, Advantages; $\boldsymbol{\Delta}$, Disadvantages. 
viral gene therapy when administered with other treatment modalities, such as advanced radiation therapy and molecular targeted therapy, would demonstrate greater efficacy over the treatment with viral agents alone. For instance, brain radiotherapy can disrupt the BBB facilitating enhanced viral delivery. Patient safety does not appear to be a significant concern in the clinical gene therapy studies in patients with GBM. Although an ideal vector has yet to be developed, future treatment of GBM will likely incorporate multimodal therapy to study synergistic relationships between improved gene therapy and current radiation and chemotherapeutic regimens. A significant obstacle to the development of multidrug combination clinical trial protocols includes legal entanglements that preclude a drug from one company from being combined with a second. The design of combination protocols including gene therapies may ultimately alleviate some of these legal obstructions. As the field of gene therapy moves forward, the use of gene therapy in the treatment of GBM will become an increasingly promising area of research to support the therapeutic regimens of surgery, radiation, and chemotherapy.

\section{Abbreviations \\ 5-FC: 5-fluorocytosine; 5-FU: 5-fluorouracil; AAV: Adeno-associated virus; $\mathrm{AV}$ : Adenovirus; BBB: Blood brain barrier; bp: Base pair; CD: Cytosine deaminase; CEA: Carcinogenic embryonic antigen; CMV: Cytomegalovirus; CNS: Central nervous system; CSC: Cancer stem cell; DC: Dendritic cell; DNA: Deoxyribonucleic acid; E1B: Early region 1B; Edm: Edmonston strain; EIF-2a: Eukaryotic initiation factor-2 alpha; Flt3L: Fms-like tyrosine kinase-3 ligand; GBM: Glioblastoma multiforme; GCV: Ganciclovir; GSC: Glioma stem cell; HSV: Herpes simplex virus; ICP: Infected cell protein; IFN: Interferon; IL: Interleukin; IRES: Internal ribosome entry site; \\ MHC: Majorhistocompatibility; MV: Measles virus; NDV: Newcastle disease virus; NK: Natural killer; PKR: Protein Kinase R; PTEN: Phosphatase and tensin homologue; Rb: Retinoblastoma; RR: Ribonucleotide reductase; \\ TGF: Transforming growth factor; TK: Thymidine kinase; TMZ: Temozolomide; UL: Unique long; UPRT: Uracil phosphoribosyltransferase.}

\section{Competing interests}

The authors hereby declare that they have no competing interests.

\section{Authors' contributions}

$\mathrm{HO}$ drafted the manuscript and tabulated the information found in the table CAS and HO prepared the figures. CAS helped to draft the manuscript. JTR edited the final manuscript. All authors read and approved the final manuscript.

\section{Acknowledgements}

This work was supported by grants from Canadian Institute of Health Research (MOP 74610), and by funds from b.r.a.i.n.child, Meagan Bebenek Research Institute, and Laurie Berman and Wiley Family funds for brain tumor research.

\section{Author details}

${ }^{1}$ The Arthur and Sonia Labatt Brain Tumour Research Centre, The Hospital for Sick Children, Peter Gilgan Centre for Research and Learning, 686 Bay Street, 17th Floor, Toronto, ON M5G 0A4, Canada. ${ }^{2}$ Department of Neurosurgery, Juntendo University School of Medicine, 2-1-1 Hongo, Bunkyo-ku, Tokyo 113-8421, Japan. ${ }^{3}$ Department of Surgery, University of Toronto, 149 College Street, 5th Floor, Toronto, Ontario M5T 1P5, Canada. ${ }^{4}$ Division of Neurosurgery, The Hospital for Sick Children, Suite 1503, 555 University Avenue, Toronto, Ontario M5G 1X8, Canada.
Received: 30 March 2014 Accepted: 27 June 2014

Published: 8 July 2014

\section{References}

1. Wen PY, Kesari S: Malignant gliomas in adults. N Engl J Med 2008, 359:492-507.

2. Stupp R, Mason WP, van den Bent MJ, Weller M, Fisher B, Taphoorn MJ, Belanger K, Brandes AA, Marosi C, Bogdahn U, Curschmann J, Janzer RC, Ludwin SK, Gorlia T, Allgeier A, Lacombe D, Cairncross JG, Eisenhauer E, Mirimanoff RO: Radiotherapy plus concomitant and adjuvant temozolomide for glioblastoma. N Engl J Med 2005, 352:987-996.

3. Stupp R, Hegi ME, Mason WP, van den Bent MJ, Taphoorn MJ, Janzer RC, Ludwin SK, Allgeier A, Fisher B, Belanger K, Hau P, Brandes AA, Gijtenbeek J, Marosi C, Vecht CJ, Mokhtari K, Wesseling P, Villa S, Eisenhauer E, Gorlia T, Weller M, Lacombe D, Cairncross JG, Mirimanoff RO: Effects of radiotherapy with concomitant and adjuvant temozolomide versus radiotherapy alone on survival in glioblastoma in a randomised phase III study: 5-year analysis of the EORTC-NCIC trial. Lancet Oncol 2009, 10:459-466.

4. van den Bent MJ, Hegi ME, Stupp R: Recent developments in the use of chemotherapy in brain tumours. Eur J Cancer 2006, 42:582-588.

5. Kanu OO, Mehta A, Di C, Lin N, Bortoff K, Bigner DD, Yan H, Adamson DC: Glioblastoma multiforme: a review of therapeutic targets. Expert Opin Ther Targets 2009, 13:701-718.

6. Altaner C: Glioblastoma and stem cells. Neoplasma 2008, 55:369-374.

7. Huang Z, Cheng L, Guryanova OA, Wu Q, Bao S: Cancer stem cells in glioblastoma-molecular signaling and therapeutic targeting. Protein Cell 2010, 1:638-655

8. Nduom EK, Hadjipanayis CG, Van Meir EG: Glioblastoma cancer stem-like cells: implications for pathogenesis and treatment. Cancer J 2012, 18:100-106.

9. Bansal K, Engelhard HH: Gene therapy for brain tumors. Curr Oncol Rep 2000, 2:463-472.

10. Russell SJ, Peng KW, Bell JC: Oncolytic virotherapy. Nat Biotechnol 2012, 30:658-670.

11. Sonabend AM, Ulasov IV, Lesniak MS: Gene therapy trials for the treatment of high-grade gliomas. Gene Ther Mol Biol 2007, 11:79-92.

12. Culver KW, Ram Z, Wallbridge S, Ishii H, Oldfield EH, Blaese RM: In vivo gene transfer with retroviral vector-producer cells for treatment of experimental brain tumors. Science 1992, 256:1550-1552.

13. Natsume A, Yoshida J: Gene therapy for high-grade glioma: current approaches and future directions. Cell Adh Migr 2008, 2:186-191.

14. Yoshida J, Mizuno M: Clinical gene therapy for brain tumors. Liposomal delivery of anticancer molecule to glioma. J Neurooncol 2003, 65:261-267.

15. Juratli TA, Schackert G, Krex D: Current status of local therapy in malignant gliomas-a clinical review of three selected approaches. Pharmacol Ther 2013, 139:341-358.

16. Rainov NG, Heidecke V: Clinical development of experimental therapies for malignant glioma. Sultan Qaboos Univ Med J 2011, 11:5-28.

17. Tobias A, Ahmed A, Moon KS, Lesniak MS: The art of gene therapy for glioma: a review of the challenging road to the bedside. J Neurol Neurosurg Psychiatry 2013, 84:213-222

18. Duarte S, Carle G, Faneca H, de Lima MC, Pierrefite-Carle V: Suicide gene therapy in cancer: where do we stand now? Cancer Lett 2012, 324:160-170.

19. Kaliberov SA, Market JM, Gillespie GY, Krendelchtchikova V, Della Manna D, Sellers JC, Kaliberova LN, Black ME, Buchsbaum DJ: Mutation of Escherichia coli cytosine deaminase significantly enhances molecular chemotherapy of human glioma. Gene Ther 2007, 14:1111-1119.

20. Immonen A, Vapalahti M, Tyynela K, Hurskainen H, Sandmair A, Vanninen R, Langford G, Murray N, Yla-Herttuala S: AdvHSV-tk gene therapy with intravenous ganciclovir improves survival in human malignant glioma: a randomised, controlled study. Mol Ther 2004, 10:967-972.

21. Germano IM, Fable J, Gultekin SH, Silvers A: Adenovirus/herpes simplex-thymidine kinase/ganciclovir complex: preliminary results of a phase I trial in patients with recurrent malignant gliomas. J Neurooncol 2003, 65:279-289.

22. Sandmair AM, Loimas $S$, Puranen $P$, Immonen A, Kossila M, Puranen $M$,

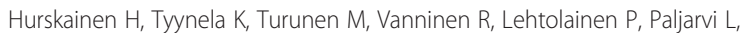
Johansson R, Vapalahti M, Yla-Herttuala S: Thymidine kinase gene therapy for human malignant glioma, using replication-deficient retroviruses or adenoviruses. Hum Gene Ther 2000, 11:2197-2205. 
23. Trask TW, Trask RP, Aguilar-Cordova E, Shine HD, Wyde PR, Goodman JC, Hamilton WJ, Rojas-Martinez A, Chen SH, Woo SL, Grossman RG: Phase I study of adenoviral delivery of the HSV-tk gene and ganciclovir administration in patients with current malignant brain tumors. Mol Ther 2000, 1:195-203.

24. Ito S, Natsume A, Shimato S, Ohno M, Kato T, Chansakul P, Wakabayashi T, Kim SU: Human neural stem cells transduced with IFN-beta and cytosine deaminase genes intensify bystander effect in experimental glioma. Cancer Gene Ther 2010, 17:299-306.

25. Valerie K, Hawkins W, Farnsworth J, Schmidt-Ullrich R, Lin PS, Amir C, Feden $\mathrm{J}$ : Substantially improved in vivo radiosensitization of rat glioma with mutant HSV-TK and acyclovir. Cancer Gene Ther 2001, 8:3-8.

26. Kroeger KM, Muhammad AK, Baker GJ, Assi H, Wibowo MK, Xiong W, Yagiz K, Candolfi M, Lowenstein PR, Castro MG: Gene therapy and virotherapy: novel therapeutic approaches for brain tumors. Discov Med 2010, 10:293-304.

27. Kwiatkowska A, Nandhu MS, Behera P, Chiocca EA, Viapiano MS: Strategies in gene therapy for glioblastoma. Cancers (Basel) 2013, 5:1271-1305.

28. Moolten FL: Tumor chemosensitivity conferred by inserted herpes thymidine kinase genes: paradigm for a prospective cancer control strategy. Cancer Res 1986, 46:5276-5281.

29. Elion GB: The biochemistry and mechanism of action of acyclovir. J Antimicrob Chemother 1983, 12(Suppl B):9-17.

30. Fischer U, Steffens S, Frank S, Rainov NG, Schulze-Osthoff K, Kramm CM: Mechanisms of thymidine kinase/ganciclovir and cytosine deaminase/ 5-fluorocytosine suicide gene therapy-induced cell death in glioma cells. Oncogene 2005, 24:1231-1243.

31. Paillard F: Bystander effects in enzyme/prodrug gene therapy. Hum Gene Ther 1997, 8:1733-1735.

32. Touraine RL, Vahanian N, Ramsey WJ, Blaese RM: Enhancement of the herpes simplex virus thymidine kinase/ganciclovir bystander effect and its antitumor efficacy in vivo by pharmacologic manipulation of gap junctions. Hum Gene Ther 1998, 9:2385-2391.

33. Touraine RL, Ishii-Morita H, Ramsey WJ, Blaese RM: The bystander effect in the HSVtk/ganciclovir system and its relationship to gap junctional communication. Gene Ther 1998, 5:1705-1711.

34. Fick J, Barker FG 2nd, Dazin P, Westphale EM, Beyer EC, Israel MA: The extent of heterocellular communication mediated by gap junctions is predictive of bystander tumor cytotoxicity in vitro. Proc Natl Acad Sci US A 1995, 92:11071-11075.

35. Hamel W, Magnelli L, Chiarugi VP, Israel MA: Herpes simplex virus thymidine kinase/ganciclovir-mediated apoptotic death of bystander cells. Cancer Res 1996, 56:2697-2702.

36. van Dillen IJ, Mulder NH, Vaalburg W, de Vries EF, Hospers GA: Influence of the bystander effect on HSV-tk/GCV gene therapy. A review. Curr Gene Ther 2002, 2:307-322.

37. Freeman SM, Abboud CN, Whartenby KA, Packman CH, Koeplin DS, Moolten FL, Abraham GN: The "bystander effect": tumor regression when a fraction of the tumor mass is genetically modified. Cancer Res 1993, 53:5274-5283

38. Ram Z, Culver KW, Walbridge S, Blaese RM, Oldfield EH: In situ retroviral-mediated gene transfer for the treatment of brain tumors in rats. Cancer Res 1993, 53:83-88.

39. Prados MD, McDermott M, Chang SM, Wilson CB, Fick J, Culver KW, Van Gilder J, Keles GE, Spence A, Berger M: Treatment of progressive or recurrent glioblastoma multiforme in adults with herpes simplex virus thymidine kinase gene vector-producer cells followed by intravenous ganciclovir administration: a phase I/II multi-institutional trial. J Neurooncol 2003, 65:269-278.

40. Valerie K, Brust D, Farnsworth J, Amir C, Taher MM, Hershey C, Feden J: Improved radiosensitization of rat glioma cells with adenovirusexpressed mutant herpes simplex virus-thymidine kinase in combination with acyclovir. Cancer Gene Ther 2000, 7:879-884.

41. Kim SH, Kim JH, Kolozsvary A, Brown SL, Freytag SO: Preferential radiosensitization of $9 \mathrm{~L}$ glioma cells transduced with HSV-tk gene by acyclovir. J Neurooncol 1997, 33:189-194.

42. Rainov NG, Fels C, Droege JW, Schafer C, Kramm CM, Chou TC: Temozolomide enhances herpes simplex virus thymidine kinase/ganciclovir therapy of malignant glioma. Cancer Gene Ther 2001, 8:662-668.

43. Rainov NG: A phase III clinical evaluation of herpes simplex virus type 1 thymidine kinase and ganciclovir gene therapy as an adjuvant to surgical resection and radiation in adults with previously untreated glioblastoma multiforme. Hum Gene Ther 2000, 11:2389-2401.
44. Sandmair AM, Turunen M, Tyynela K, Loimas S, Vainio P, Vanninen R, Vapalahti M, Bjerkvig R, Janne J, Yla-Herttuala S: Herpes simplex virus thymidine kinase gene therapy in experimental rat BT4C glioma model: effect of the percentage of thymidine kinase-positive glioma cells on treatment effect, survival time, and tissue reactions. Cancer Gene Ther 2000, 7:413-421.

45. Mullen CA, Kilstrup M, Blaese RM: Transfer of the bacterial gene for cytosine deaminase to mammalian cells confers lethal sensitivity to 5-fluorocytosine: a negative selection system. Proc Natl Acad Sci U S A 1992, 89:33-37.

46. Schilsky RL: Biochemical and clinical pharmacology of 5-fluorouracil. Oncology (Williston Park) 1998, 12:13-18.

47. Kurozumi K, Tamiya T, Ono Y, Otsuka S, Kambara H, Adachi Y, Ichikawa T, Hamada H, Ohmoto T: Apoptosis induction with 5-fluorocytosine/cytosine deaminase gene therapy for human malignant glioma cells mediated by adenovirus. J Neurooncol 2004, 66:117-127.

48. Altaner C: Prodrug cancer gene therapy. Cancer Lett 2008, 270:191-201.

49. Dachs GU, Tupper J, Tozer GM: From bench to bedside for gene-directed enzyme prodrug therapy of cancer. Anticancer Drugs 2005, 16:349-359.

50. Trinh QT, Austin EA, Murray DM, Knick VC, Huber BE: Enzyme/prodrug gene therapy: comparison of cytosine deaminase/5-fluorocytosine versus thymidine kinase/ganciclovir enzyme/prodrug systems in a human colorectal carcinoma cell line. Cancer Res 1995, 55:4808-4812.

51. Dong Y, Wen P, Manome Y, Parr M, Hirshowitz A, Chen L, Hirschowitz EA, Crystal R, Weichselbaum R, Kufe DW, Fine HA: In vivo replication-deficient adenovirus vector-mediated transduction of the cytosine deaminase gene sensitizes glioma cells to 5-fluorocytosine. Hum Gene Ther 1996, 7:713-720.

52. Adachi Y, Tamiya T, Ichikawa T, Terada K, Ono Y, Matsumoto K, Furuta T, Hamada $H$, Ohmoto T: Experimental gene therapy for brain tumors using adenovirus-mediated transfer of cytosine deaminase gene and uracil phosphoribosyltransferase gene with 5-fluorocytosine. Hum Gene Ther 2000, 11:77-89.

53. Kambara H, Tamiya T, Ono Y, Ohtsuka S, Terada K, Adachi Y, Ichikawa T, Hamada $\mathrm{H}$, Ohmoto T: Combined radiation and gene therapy for brain tumors with adenovirus-mediated transfer of cytosine deaminase and uracil phosphoribosyltransferase genes. Cancer Gene Ther 2002, 9:840-845.

54. Ostertag D, Amundson KK, Lopez Espinoza F, Martin B, Buckley T, da Silva AP G, Lin AH, Valenta DT, Perez OD, Ibanez CE, Chen Cl, Pettersson PL, Burnett R, Daublebsky V, Hlavaty J, Gunzburg W, Kasahara N, Gruber HE, Jolly DJ, Robbins JM: Brain tumor eradication and prolonged survival from intratumoral conversion of 5-fluorocytosine to 5-fluorouracil using a nonlytic retroviral replicating vector. Neuro Oncol 2012, 14:145-159.

55. Huang TT, Hlavaty J, Ostertag D, Espinoza FL, Martin B, Petznek H, Rodriguez-Aguirre M, Ibanez CE, Kasahara N, Gunzburg W, Gruber HE, Pertschuk D, Jolly DJ, Robbins JM: Toca 511 gene transfer and 5 -fluorocytosine in combination with temozolomide demonstrates synergistic therapeutic efficacy in a temozolomide-sensitive glioblastoma model. Cancer Gene Ther 2013, 20:544-551.

56. Uchida N, Buck DW, He D, Reitsma MJ, Masek M, Phan TV, Tsukamoto AS, Gage FH, Weissman IL: Direct isolation of human central nervous system stem cells. Proc Natl Acad Sci U S A 2000, 97:14720-14725.

57. Reynolds BA, Weiss S: Generation of neurons and astrocytes from isolated cells of the adult mammalian central nervous system. Science 1992, 255:1707-1710.

58. Gage FH: Mammalian neural stem cells. Science 2000, 287:1433-1438

59. Aboody KS, Brown A, Rainov NG, Bower KA, Liu S, Yang W, Small JE, Herrlinger U, Ourednik V, Black PM, Breakefield XO, Snyder EY: Neural stem cells display extensive tropism for pathology in adult brain: evidence from intracranial gliomas. Proc Natl Acad Sci U S A 2000, 97:12846-12851.

60. Aboody KS, Najbauer J, Danks MK: Stem and progenitor cell-mediated tumor selective gene therapy. Gene Ther 2008, 15:739-752.

61. Barresi V, Belluardo N, Sipione S, Mudo G, Cattaneo E, Condorelli DF: Transplantation of prodrug-converting neural progenitor cells for brain tumor therapy. Cancer Gene Ther 2003, 10:396-402.

62. Rath P, Shi H, Maruniak JA, Litofsky NS, Maria BL, Kirk MD: Stem cells as vectors to deliver HSV/tk gene therapy for malignant gliomas. Curr Stem Cell Res Ther 2009, 4:44-49.

63. Murphy AM, Rabkin SD: Current status of gene therapy for brain tumors. Trans/ Res 2013, 161:339-354.

64. Dvorak HF: Tumors: wounds that do not heal. Similarities between tumor stroma generation and wound healing. N Engl J Med 1986, 315:1650-1659. 
65. Bexell D, Scheding S, Bengzon J: Toward brain tumor gene therapy using multipotent mesenchymal stromal cell vectors. Mol Ther 2010, 18:1067-1075.

66. Hingtgen S, Ren X, Terwilliger E, Classon M, Weissleder R, Shah K: Targeting multiple pathways in gliomas with stem cell and viral delivered S-TRAIL and Temozolomide. Mol Cancer Ther 2008, 7:3575-3585.

67. Chang DY, Yoo SW, Hong Y, Kim S, Kim SJ, Yoon SH, Cho KG, Paek SH, Lee YD, Kim SS, Suh-Kim H: The growth of brain tumors can be suppressed by multiple transplantation of mesenchymal stem cells expressing cytosine deaminase. Int J Cancer 2010, 127:1975-1983.

68. Bagci-Onder T, Wakimoto $\mathrm{H}$, Anderegg M, Cameron C, Shah K: A dual PI3K/ mTOR inhibitor, PI-103, cooperates with stem cell-delivered TRAIL in experimental glioma models. Cancer Res 2011, 71:154-163.

69. Assi H, Candolfi M, Baker G, Mineharu Y, Lowenstein PR, Castro MG: Gene therapy for brain tumors: basic developments and clinical implementation. Neurosci Lett 2012, 527:71-77.

70. Castro MG, Candolfi M, Kroeger K, King GD, Curtin JF, Yagiz K, Mineharu Y, Assi H, Wibowo M, Ghulam Muhammad AK, Foulad D, Puntel M, Lowenstein PR: Gene therapy and targeted toxins for glioma. Curr Gene Ther 2011, 11:155-180.

71. Samaranayake H, Maatta AM, Pikkarainen J, Yla-Herttuala S: Future prospects and challenges of antiangiogenic cancer gene therapy. Hum Gene Ther 2010, 21:381-396.

72. Kaufmann JK, Chiocca EA: Glioma virus therapies between bench and bedside. Neuro Oncol 2014, 16:334-351.

73. Chiocca EA: Oncolytic viruses. Nat Rev Cancer 2002, 2:938-950.

74. Ikeda K, Ichikawa T, Wakimoto H, Silver JS, Deisboeck TS, Finkelstein D, Harsh GR, Louis DN, Bartus RT, Hochberg FH, Chiocca EA: Oncolytic virus therapy of multiple tumors in the brain requires suppression of innate and elicited antiviral responses. Nat Med 1999, 5:881-887.

75. Allen C, Opyrchal M, Aderca I, Schroeder MA, Sarkaria JN, Domingo E, Federspiel MJ, Galanis E: Oncolytic measles virus strains have significant antitumor activity against glioma stem cells. Gene Ther 2013, 20:444-449.

76. Selznick LA, Shamji MF, Fecci P, Gromeier M, Friedman AH, Sampson J: Molecular strategies for the treatment of malignant glioma-genes, viruses, and vaccines. Neurosurg Rev 2008, 31:141-155. discussion 155

77. Iwami K, Natsume A, Wakabayashi T: Gene therapy for high-grade glioma. Neurol Med Chir (Tokyo) 2010, 50:727-736.

78. Mineta T, Rabkin SD, Yazaki T, Hunter WD, Martuza RL: Attenuated multi-mutated herpes simplex virus-1 for the treatment of malignant gliomas. Nat Med 1995, 1:938-943.

79. Goldstein DJ, Weller SK: Factor(s) present in herpes simplex virus type 1 -infected cells can compensate for the loss of the large subunit of the viral ribonucleotide reductase: characterization of an ICP6 deletion mutant. Virology 1988, 166:41-51.

80. Shah AC, Benos D, Gillespie GY, Markert JM: Oncolytic viruses: clinical applications as vectors for the treatment of malignant gliomas. J Neurooncol 2003, 65:203-226.

81. Aghi M, Visted T, Depinho RA, Chiocca EA: Oncolytic herpes virus with defective ICP6 specifically replicates in quiescent cells with homozygous genetic mutations in p16. Oncogene 2008, 27:4249-4254.

82. Hoshino T, Prados M, Wilson CB, Cho KG, Lee KS, Davis RL: Prognostic implications of the bromodeoxyuridine labeling index of human gliomas. J Neurosurg 1989, 71:335-341.

83. Coen DM, Goldstein DJ, Weller SK: Herpes simplex virus ribonucleotide reductase mutants are hypersensitive to acyclovir. Antimicrob Agents Chemother 1989, 33:1395-1399.

84. Haseley A, Alvarez-Breckenridge C, Chaudhury AR, Kaur B: Advances in oncolytic virus therapy for glioma. Recent Pat CNS Drug Discov 2009, 4:1-13.

85. He B, Gross M, Roizman B: The gamma(1)34.5 protein of herpes simplex virus 1 complexes with protein phosphatase 1alpha to dephosphorylate the alpha subunit of the eukaryotic translation initiation factor 2 and preclude the shutoff of protein synthesis by double-stranded RNA-activated protein kinase. Proc Natl Acad Sci U S A 1997, 94:843-848.

86. Chou J, Kern ER, Whitley RJ, Roizman B: Mapping of herpes simplex virus-1 neurovirulence to gamma 134.5, a gene nonessential for growth in culture. Science 1990, 250:1262-1266.

87. Nandi S, Lesniak MS: Adenoviral virotherapy for malignant brain tumors. Expert Opin Biol Ther 2009, 9:737-747.

88. Parker JN, Bauer DF, Cody JJ, Markert JM: Oncolytic viral therapy of malignant glioma. Neurotherapeutics 2009, 6:558-569.
89. Zemp FJ, Corredor JC, Lun X, Muruve DA, Forsyth PA: Oncolytic viruses as experimental treatments for malignant gliomas: using a scourge to treat a devil. Cytokine Growth Factor Rev 2010, 21:103-117.

90. Chambers R, Gillespie GY, Soroceanu L, Andreansky S, Chatterjee S, Chou J, Roizman B, Whitley RJ: Comparison of genetically engineered herpes simplex viruses for the treatment of brain tumors in a scid mouse model of human malignant glioma. Proc Natl Acad Sci U S A 1995, 92:1411-1415.

91. Hunter WD, Martuza RL, Feigenbaum F, Todo T, Mineta T, Yazaki T, Toda M, Newsome JT, Platenberg RC, Manz HJ, Rabkin SD: Attenuated, replication-competent herpes simplex virus type 1 mutant G207: safety evaluation of intracerebral injection in nonhuman primates. J Virol 1999 73:6319-6326.

92. Markert JM, Malick A, Coen DM, Martuza RL: Reduction and elimination of encephalitis in an experimental glioma therapy model with attenuated herpes simplex mutants that retain susceptibility to acyclovir. Neurosurgery 1993, 32:597-603.

93. Sundaresan P, Hunter WD, Martuza RL, Rabkin SD: Attenuated, replication-competent herpes simplex virus type 1 mutant G207: safety evaluation in mice. J Virol 2000, 74:3832-3841.

94. Markert JM, Medlock MD, Rabkin SD, Gillespie GY, Todo T, Hunter WD, Palmer CA, Feigenbaum F, Tornatore C, Tufaro F, Martuza RL: Conditionally replicating herpes simplex virus mutant, G207 for the treatment of malignant glioma: results of a phase I trial. Gene Ther 2000, 7:867-874.

95. Markert JM, Liechty PG, Wang W, Gaston S, Braz E, Karrasch M, Nabors LB, Markiewicz M, Lakeman AD, Palmer CA, Parker JN, Whitley RJ, Gillespie GY: Phase lb trial of mutant herpes simplex virus G207 inoculated pre-and post-tumor resection for recurrent GBM. Mol Ther 2009, 17:199-207.

96. MacLean AR, ul-Fareed M, Robertson L, Harland J, Brown SM: Herpes simplex virus type 1 deletion variants 1714 and 1716 pinpoint neurovirulence-related sequences in Glasgow strain 17+ between immediate early gene 1 and the 'a' sequence. J Gen Virol 1991, 72(Pt 3):631-639.

97. Valyi-Nagy T, Fareed MU, O'Keefe JS, Gesser RM, MacLean AR, Brown SM, Spivack JG, Fraser NW: The herpes simplex virus type 1 strain 17+ gamma 34.5 deletion mutant 1716 is avirulent in SCID mice. J Gen Virol 1994, 75(Pt 8):2059-2063.

98. Kesari S, Randazzo BP, Valyi-Nagy T, Huang QS, Brown SM, MacLean AR, Lee VM, Trojanowski JQ, Fraser NW: Therapy of experimental human brain tumors using a neuroattenuated herpes simplex virus mutant. Lab Invest 1995, 73:636-648

99. McKie EA, Brown SM, MacLean AR, Graham DI: Histopathological responses in the CNS following inoculation with a non-neurovirulent mutant (1716) of herpes simplex virus type 1 (HSV 1): relevance for gene and cancer therapy. Neuropathol Appl Neurobiol 1998, 24:367-372.

100. Randazzo BP, Kesari S, Gesser RM, Alsop D, Ford JC, Brown SM, Maclean A, Fraser NW: Treatment of experimental intracranial murine melanoma with a neuroattenuated herpes simplex virus 1 mutant. Virology 1995, 211:94-101.

101. Rampling R, Cruickshank G, Papanastassiou V, Nicoll J, Hadley D, Brennan D, Petty R, MacLean A, Harland J, McKie E, Mabbs R, Brown M: Toxicity evaluation of replication-competent herpes simplex virus (ICP 34.5 null mutant 1716) in patients with recurrent malignant glioma. Gene Ther 2000, 7:859-866

102. Papanastassiou V, Rampling R, Fraser M, Petty R, Hadley D, Nicoll J, Harland J, Mabbs R, Brown M: The potential for efficacy of the modified (ICP 34.5 (-)) herpes simplex virus HSV1716 following intratumoural injection into human malignant glioma: a proof of principle study. Gene Ther 2002, 9:398-406.

103. Harrow S, Papanastassiou V, Harland J, Mabbs R, Petty R, Fraser M, Hadley D, Patterson J, Brown SM, Rampling R: HSV1716 injection into the brain adjacent to tumour following surgical resection of high-grade glioma: safety data and long-term survival. Gene Ther 2004, 11:1648-1658.

104. Chiocca EA, Broaddus WC, Gillies GT, Visted T, Lamfers ML: Neurosurgical delivery of chemotherapeutics, targeted toxins, genetic and viral therapies in neuro-oncology. J Neurooncol 2004, 69:101-117.

105. Mackie RM, Stewart B, Brown SM: Intralesional injection of herpes simplex virus 1716 in metastatic melanoma. Lancet 2001, 357:525-526.

106. Kanai R, Zaupa C, Sgubin D, Antoszczyk SJ, Martuza RL, Wakimoto H, Rabkin SD: Effect of gamma34.5 deletions on oncolytic herpes simplex virus activity in brain tumors. J Virol 2012, 86:4420-4431.

107. Wakimoto H, Kesari S, Farrell CJ, Curry WT Jr, Zaupa C, Aghi M, Kuroda T, Stemmer-Rachamimov A, Shah K, Liu TC, Jeyaretna DS, Debasitis J, Pruszak J, 
Martuza RL, Rabkin SD: Human glioblastoma-derived cancer stem cells: establishment of invasive glioma models and treatment with oncolytic herpes simplex virus vectors. Cancer Res 2009, 69:3472-3481.

108. Todo T, Martuza RL, Rabkin SD, Johnson PA: Oncolytic herpes simplex virus vector with enhanced MHC class I presentation and tumor cell killing. Proc Natl Acad Sci U S A 2001, 98:6396-6401.

109. Todo T: Oncolytic virus therapy using genetically engineered herpes simplex viruses. Front Biosci 2008, 13:2060-2064

110. Jiang W, Kim BY, Rutka JT, Chan WC: Advances and challenges of nanotechnology-based drug delivery systems. Expert Opin Drug Deliv 2007, 4:621-633.

111. Gambini E, Reisoli E, Appolloni I, Gatta V, Campadelli-Fiume G, Menotti L, Malatesta P: Replication-competent herpes simplex virus retargeted to HER2 as therapy for high-grade glioma. Mol Ther 2012, 20:994-1001.

112. Longo SL, Griffith C, Glass A, Shillitoe EJ, Post DE: Development of an oncolytic herpes simplex virus using a tumor-specific HIF-responsive promoter. Cancer Gene Ther 2011, 18:123-134.

113. Lang FF, Yung WK, Sawaya R, Tofilon PJ: Adenovirus-mediated p53 gene therapy for human gliomas. Neurosurgery 1999, 45:1093-1104.

114. Bischoff JR, Kirn DH, Williams A, Heise C, Horn S, Muna M, Ng L, Nye JA, Sampson-Johannes A, Fattaey A, McCormick F: An adenovirus mutant that replicates selectively in p53-deficient human tumor cells. Science 1996, 274:373-376.

115. Heise C, Sampson-Johannes A, Williams A, McCormick F, Von Hoff DD, Kirn DH: ONYX-015, an E1B gene-attenuated adenovirus, causes tumor-specific cytolysis and antitumoral efficacy that can be augmented by standard chemotherapeutic agents. Nat Med 1997, 3:639-645.

116. Hall AR, Dix BR, O'Carroll SJ, Braithwaite AW: p53-dependent cell death/apoptosis is required for a productive adenovirus infection. Nat Med 1998, 4:1068-1072.

117. Geoerger B, Grill J, Opolon P, Morizet J, Aubert G, Terrier-Lacombe MJ, Bressac De-Paillerets B, Barrois M, Feunteun J, Kirn DH, Vassal G: Oncolytic activity of the E1B-55 kDa-deleted adenovirus ONYX-015 is independent of cellular p53 status in human malignant glioma xenografts. Cancer Res 2002, 62:764-772.

118. O'Shea CC, Johnson L, Bagus B, Choi S, Nicholas C, Shen A, Boyle L, Pandey K, Soria C, Kunich J, Shen Y, Habets G, Ginzinger D, McCormick F: Late viral RNA export, rather than p53 inactivation, determines ONYX-015 tumor selectivity. Cancer Cell 2004, 6:611-623.

119. Goodrum FD, Ornelles DA: $p 53$ status does not determine outcome of E1B 55-kilodalton mutant adenovirus lytic infection. J Virol 1998, 72:9479-9490.

120. Rothmann T, Hengstermann A, Whitaker NJ, Scheffner M, zur Hausen H: Replication of ONYX-015, a potential anticancer adenovirus, is independent of p53 status in tumor cells. J Virol 1998, 72:9470-9478.

121. Geoerger B, Grill J, Opolon P, Morizet J, Aubert G, Lecluse Y, van Beusechem WW, Gerritsen WR, Kirn DH, Vassal G: Potentiation of radiation therapy by the oncolytic adenovirus dl1520 (ONYX-015) in human malignant glioma xenografts. Br J Cancer 2003, 89:577-584.

122. Chiocca EA, Abbed KM, Tatter S, Louis DN, Hochberg FH, Barker F, Kracher J, Grossman SA, Fisher JD, Carson K, Rosenblum M, Mikkelsen T, Olson J, Markert J, Rosenfeld S, Nabors LB, Brem S, Phuphanich S, Freeman S, Kaplan R, Zwiebel J: A phase I open-label, dose-escalation, multi-institutional trial of injection with an E1B-Attenuated adenovirus, ONYX-015, into the peritumoral region of recurrent malignant gliomas, in the adjuvant setting. Mol Ther 2004, 10:958-966.

123. Makower D, Rozenblit A, Kaufman $H$, Edelman M, Lane ME, Zwiebel J, Haynes H, Wadler S: Phase II clinical trial of intralesional administration of the oncolytic adenovirus ONYX-015 in patients with hepatobiliary tumors with correlative p53 studies. Clin Cancer Res 2003, 9:693-702.

124. Nemunaitis J, Khuri F, Ganly I, Arseneau J, Posner M, Vokes E, Kuhn J, McCarty T, Landers S, Blackburn A, Romel L, Randlev B, Kaye S, Kirn D: Phase II trial of intratumoral administration of ONYX-015, a replication-selective adenovirus, in patients with refractory head and neck cancer. J Clin Oncol 2001, 19:289-298.

125. Cross D, Burmester JK: Gene therapy for cancer treatment: past, present and future. Clin Med Res 2006, 4:218-227.

126. Hamel W, Westphal M, Shepard HM: Loss in expression of the retinoblastoma gene product in human gliomas is associated with advanced disease. J Neurooncol 1993, 16:159-165.

127. Ueki K, Ono Y, Henson JW, Efird JT, von Deimling A, Louis DN: CDKN2/p16 or RB alterations occur in the majority of glioblastomas and are inversely correlated. Cancer Res 1996, 56:150-153.
128. Fueyo J, Gomez-Manzano C, Alemany R, Lee PS, McDonnell TJ, Mitlianga P, Shi YX, Levin VA, Yung WK, Kyritsis AP: A mutant oncolytic adenovirus targeting the Rb pathway produces anti-glioma effect in vivo. Oncogene 2000, 19:2-12.

129. Suzuki K, Fueyo J, Krasnykh V, Reynolds PN, Curiel DT, Alemany R: A conditionally replicative adenovirus with enhanced infectivity shows improved oncolytic potency. Clin Cancer Res 2001, 7:120-126.

130. Fueyo J, Alemany R, Gomez-Manzano C, Fuller GN, Khan A, Conrad CA, Liu TJ, Jiang H, Lemoine MG, Suzuki K, Sawaya R, Curiel DT, Yung WK, Lang FF: Preclinical characterization of the antiglioma activity of a tropismenhanced adenovirus targeted to the retinoblastoma pathway. J Natl Cancer Inst 2003, 95:652-660.

131. Lamfers ML, Grill J, Dirven CM, Van Beusechem WW, Geoerger B, Van Den Berg J, Alemany R, Fueyo J, Curiel DT, Vassal G, Pinedo HM, Vandertop WP, Gerritsen WR: Potential of the conditionally replicative adenovirus Ad5-Delta24RGD in the treatment of malignant gliomas and its enhanced effect with radiotherapy. Cancer Res 2002, 62:5736-5742.

132. Auffinger B, Ahmed AU, Lesniak MS: Oncolytic virotherapy for malignant glioma: translating laboratory insights into clinical practice. Front Oncol 2013, 3:32.

133. Dorig RE, Marcil A, Chopra A, Richardson CD: The human CD46 molecule is a receptor for measles virus (Edmonston strain). Cell 1993, 75:295-305.

134. Fishelson Z, Donin N, Zell S, Schultz S, Kirschfink M: Obstacles to cancer immunotherapy: expression of membrane complement regulatory proteins (mCRPs) in tumors. Mol Immunol 2003, 40:109-123.

135. Anderson BD, Nakamura T, Russell SJ, Peng KW: High CD46 receptor density determines preferential killing of tumor cells by oncolytic measles virus. Cancer Res 2004, 64:4919-4926.

136. Wollmann G, Ozduman K, van den Pol AN: Oncolytic virus therapy for glioblastoma multiforme: concepts and candidates. Cancer J 2012, 18:69-81.

137. Galanis E, Bateman A, Johnson K, Diaz RM, James CD, Vile R, Russell SJ: Use of viral fusogenic membrane glycoproteins as novel therapeutic transgenes in gliomas. Hum Gene Ther 2001, 12:811-821.

138. Phuong LK, Allen C, Peng KW, Giannini C, Greiner S, TenEyck CJ, Mishra PK, Macura SI, Russell SJ, Galanis EC: Use of a vaccine strain of measles virus genetically engineered to produce carcinoembryonic antigen as a novel therapeutic agent against glioblastoma multiforme. Cancer Res 2003, 63:2462-2469.

139. Peng KW, Facteau S, Wegman T, O'Kane D, Russell SJ: Non-invasive in vivo monitoring of trackable viruses expressing soluble marker peptides. Nat Med 2002, 8:527-531.

140. Allen C, Paraskevakou G, lankov I, Giannini C, Schroeder M, Sarkaria J, Puri RK, Russell SJ, Galanis E: Interleukin-13 displaying retargeted oncolytic measles virus strains have significant activity against gliomas with improved specificity. Mol Ther 2008, 16:1556-1564.

141. Paraskevakou G, Allen C, Nakamura T, Zollman P, James CD, Peng KW, Schroeder M, Russell SJ, Galanis E: Epidermal growth factor receptor (EGFR)-retargeted measles virus strains effectively target EGFR- or EGFRvIll expressing gliomas. Mol Ther 2007, 15:677-686.

142. Allen C, Vongpunsawad S, Nakamura T, James CD, Schroeder M, Cattaneo R, Giannini C, Krempski J, Peng KW, Goble JM, Uhm JH, Russell SJ, Galanis E: Retargeted oncolytic measles strains entering via the EGFRvIll receptor maintain significant antitumor activity against gliomas with increased tumor specificity. Cancer Res 2006, 66:11840-11850.

143. Gromeier M, Lachmann S, Rosenfeld MR, Gutin PH, Wimmer E: Intergeneric poliovirus recombinants for the treatment of malignant glioma. Proc Natl Acad Sci U S A 2000, 97:6803-6808.

144. Merrill MK, Bernhardt G, Sampson JH, Wikstrand CJ, Bigner DD, Gromeier M: Poliovirus receptor CD155-targeted oncolysis of glioma. Neuro Oncol 2004, 6:208-217.

145. Sloan KE, Stewart JK, Treloar AF, Matthews RT, Jay DG: CD155/PVR enhances glioma cell dispersal by regulating adhesion signaling and focal adhesion dynamics. Cancer Res 2005, 65:10930-10937.

146. Gromeier M, Bossert B, Arita M, Nomoto A, Wimmer E: Dual stem loops within the poliovirus internal ribosomal entry site control neurovirulence. J Virol 1999, 73:958-964.

147. Gromeier M, Alexander L, Wimmer E: Internal ribosomal entry site substitution eliminates neurovirulence in intergeneric poliovirus recombinants. Proc Natl Acad Sci U S A 1996, 93:2370-2375.

148. Ahmed AU, Alexiades NG, Lesniak MS: The use of neural stem cells in cancer gene therapy: predicting the path to the clinic. Curr Opin Mol Ther 2010, 12:546-552. 
149. Herrlinger U, Woiciechowski C, Sena-Esteves M, Aboody KS, Jacobs AH, Rainov NG, Snyder EY, Breakefield XO: Neural precursor cells for delivery of replication-conditional HSV-1 vectors to intracerebral gliomas. Mol Ther 2000, 1:347-357.

150. Tyler MA, Ulasov IV, Sonabend AM, Nandi S, Han Y, Marler S, Roth J, Lesniak MS: Neural stem cells target intracranial glioma to deliver an oncolytic adenovirus in vivo. Gene Ther 2009, 16:262-278.

151. Ahmed AU, Thaci B, Alexiades NG, Han Y, Qian S, Liu F, Balyasnikova IV, Ulasov IY, Aboody KS, Lesniak MS: Neural stem cell-based cell carriers enhance therapeutic efficacy of an oncolytic adenovirus in an orthotopic mouse model of human glioblastoma. Mol Ther 2011, 19:1714-1726.

152. Ahmed AU, Rolle CE, Tyler MA, Han Y, Sengupta S, Wainwright DA, Balyasnikova IV, Ulasov IV, Lesniak MS: Bone marrow mesenchymal stem cells loaded with an oncolytic adenovirus suppress the anti-adenoviral immune response in the cotton rat model. Mol Ther 2010, 18:1846-1856.

153. Yong RL, Shinojima N, Fueyo J, Gumin J, Vecil GG, Marini FC, Bogler O, Andreeff $M$, Lang FF: Human bone marrow-derived mesenchymal stem cells for intravascular delivery of oncolytic adenovirus Delta24-RGD to human gliomas. Cancer Res 2009, 69:8932-8940.

154. Borden EC, Lindner D, Dreicer R, Hussein M, Peereboom D: Secondgeneration interferons for cancer: clinical targets. Semin Cancer Biol 2000 10:125-144.

155. Wang BX, Rahbar R, Fish EN: Interferon: current status and future prospects in cancer therapy. J Interferon Cytokine Res 2011, 31:545-552.

156. Djaldetti M, Bessler H: Modulators affecting the immune dialogue between human immune and colon cancer cells. World J Gastrointest Oncol 2014, 6:129-138.

157. Sampson JH, Archer GE, Ashley DM, Fuchs HE, Hale LP, Dranoff G, Bigner DD: Subcutaneous vaccination with irradiated, cytokine-producing tumor cells stimulates CD8+ cell-mediated immunity against tumors located in the "immunologically privileged" central nervous system. Proc Natl Acad Sci U S A 1996, 93:10399-10404.

158. Wakimoto H, Abe J, Tsunoda R, Aoyagi M, Hirakawa K, Hamada H: Intensified antitumor immunity by a cancer vaccine that produces granulocyte-macrophage colony-stimulating factor plus interleukin 4. Cancer Res 1996, 56:1828-1833.

159. Belardelli F, Gresser I: The neglected role of type I interferon in the T-cell response: implications for its clinical use. Immunol Today 1996, 17:369-372.

160. Qin XQ, Tao N, Dergay A, Moy P, Fawell S, Davis A, Wilson JM, Barsoum J: Interferon-beta gene therapy inhibits tumor formation and causes regression of established tumors in immune-deficient mice. Proc Natl Acad Sci U S A 1998, 95:14411-14416.

161. Qin XQ, Beckham C, Brown JL, Lukashev M, Barsoum J: Human and mouse IFN-beta gene therapy exhibits different anti-tumor mechanisms in mouse models. Mol Ther 2001, 4:356-364.

162. Chiocca EA, Smith KM, McKinney B, Palmer CA, Rosenfeld S, Lillehei K, Hamilton A, DeMasters BK, Judy K, Kirn D: A phase I trial of Ad.hIFN-beta gene therapy for glioma. Mol Ther 2008, 16:618-626.

163. Mizuno M, Yoshida J: Effect of human interferon beta gene transfer upon human glioma, transplanted into nude mouse brain, involves induced natural killer cells. Cancer Immunol Immunother 1998, 47:227-232.

164. Yagi K, Hayashi Y, Ishida N, Ohbayashi M, Ohishi N, Mizuno M, Yoshida J: Interferon-beta endogenously produced by intratumoral injection of cationic liposome-encapsulated gene: cytocidal effect on glioma transplanted into nude mouse brain. Biochem Mol Biol Int 1994, 32:167-171.

165. Natsume A, Mizuno M, Ryuke Y, Yoshida J: Antitumor effect and cellular immunity activation by murine interferon-beta gene transfer against intracerebral glioma in mouse. Gene Ther 1999, 6:1626-1633.

166. Natsume A, Tsujimura K, Mizuno M, Takahashi T, Yoshida J: IFN-beta gene therapy induces systemic antitumor immunity against malignant glioma. J Neurooncol 2000, 47:117-124

167. Yoshida J, Mizuno M, Fujii M, Kajita Y, Nakahara N, Hatano M, Saito R, Nobayashi M, Wakabayashi T: Human gene therapy for malignant gliomas (glioblastoma multiforme and anaplastic astrocytoma) by in vivo transduction with human interferon beta gene using cationic liposomes. Hum Gene Ther 2004, 15:77-86.

168. Wakabayashi T, Natsume A, Hashizume Y, Fujii M, Mizuno M, Yoshida J: A phase I clinical trial of interferon-beta gene therapy for high-grade glioma: novel findings from gene expression profiling and autopsy. J Gene Med 2008, 10:329-339.
169. Motomura K, Natsume A, Kishida Y, Higashi H, Kondo Y, Nakasu Y, Abe T, Namba $H$, Wakai $K$, Wakabayashi T: Benefits of interferon-beta and temozolomide combination therapy for newly diagnosed primary glioblastoma with the unmethylated MGMT promoter: a multicenter study. Cancer 2011, 117:1721-1730.

170. Schroder K, Hertzog PJ, Ravasi T, Hume DA: Interferon-gamma: an overview of signals, mechanisms and functions. J Leukoc Bio/ 2004, 75:163-189.

171. Knupfer MM, Poppenborg H, Van Gool S, Domula M, Wolff JE: Interferon-gamma inhibits proliferation and adhesion of T98G human malignant glioma cells in vitro. Klin Padiatr 1997, 209:271-274.

172. Ehtesham M, Samoto K, Kabos P, Acosta FL, Gutierrez MA, Black KL, Yu JS: Treatment of intracranial glioma with in situ interferon-gamma and tumor necrosis factor-alpha gene transfer. Cancer Gene Ther 2002, 9:925-934.

173. Enderlin M, Kleinmann EV, Struyf S, Buracchi C, Vecchi A, Kinscherf R, Kiessling F, Paschek S, Sozzani S, Rommelaere J, Cornelis JJ, Van Damme J, Dinsart C. TNF-alpha and the IFN-gamma-inducible protein 10 (IP-10/CXCL-10) delivered by parvoviral vectors act in synergy to induce antitumor effects in mouse glioblastoma. Cancer Gene Ther 2009, 16:149-160.

174. Sidky YA, Borden EC: Inhibition of angiogenesis by interferons: effects on tumor- and lymphocyte-induced vascular responses. Cancer Res 1987, 47:5155-5161.

175. Einhorn S, Grander D: Why do so many cancer patients fail to respond to interferon therapy? J Interferon Cytokine Res 1996, 16:275-281.

176. Grander D, Einhorn S: Interferon and malignant disease-how does it work and why doesn't it always? Acta Oncol 1998, 37:331-338.

177. Colombo MP, Trinchieri G: Interleukin-12 in anti-tumor immunity and immunotherapy. Cytokine Growth Factor Rev 2002, 13:155-168.

178. Ma X, Chow JM, Gri G, Carra G, Gerosa F, Wolf SF, Dzialo R, Trinchieri G: The interleukin 12 p40 gene promoter is primed by interferon gamma in monocytic cells. J Exp Med 1996, 183:147-157.

179. Chen B, Timiryasova TM, Andres ML, Kajioka EH, Dutta-Roy R, Gridley DS, Fodor I: Evaluation of combined vaccinia virus-mediated antitumor gene therapy with $\mathrm{p} 53, \mathrm{IL}-2$, and IL-12 in a glioma model. Cancer Gene Ther 2000, 7:1437-1447.

180. Chiu TL, Wang MJ, Su CC: The treatment of glioblastoma multiforme through activation of microglia and TRAIL induced by rAAV2-mediated IL-12 in a syngeneic rat model. J Biomed Sci 2012, 19:45.

181. Hellums EK, Markert JM, Parker JN, He B, Perbal B, Roizman B, Whitley RJ, Langford CP, Bharara S, Gillespie GY: Increased efficacy of an interleukin-12-secreting herpes simplex virus in a syngeneic intracranial murine glioma model. Neuro Oncol 2005, 7:213-224.

182. Markert JM, Cody JJ, Parker JN, Coleman JM, Price KH, Kern ER, Quenelle DC, Lakeman AD, Schoeb TR, Palmer CA, Cartner SC, Gillespie GY, Whitley RJ: Preclinical evaluation of a genetically engineered herpes simplex virus expressing interleukin-12. J Virol 2012, 86:5304-5313.

183. Colombo F, Barzon L, Franchin E, Pacenti M, Pinna V, Danieli D, Zanusso M, Palu G: Combined HSV-TK/LL-2 gene therapy in patients with recurrent glioblastoma multiforme: biological and clinical results. Cancer Gene Ther 2005, 12:835-848.

184. Puri RK, Leland P, Kreitman RJ, Pastan I: Human neurological cancer cells express interleukin-4 (IL-4) receptors which are targets for the toxic effects of IL4-Pseudomonas exotoxin chimeric protein. Int I Cancer 1994, 58:574-581.

185. Hu-Li J, Shevach EM, Mizuguchi J, Ohara J, Mosmann T, Paul WE: B cell stimulatory factor 1 (interleukin 4 ) is a potent costimulant for normal resting T lymphocytes. J Exp Med 1987, 165:157-172.

186. Kawakami Y, Rosenberg SA, Lotze MT: Interleukin 4 promotes the growth of tumor-infiltrating lymphocytes cytotoxic for human autologous melanoma. J Exp Med 1988, 168:2183-2191.

187. Noelle R, Krammer PH, Ohara J, Uhr JW, Vitetta ES: Increased expression of la antigens on resting B cells: an additional role for B-cell growth factor. Proc Natl Acad Sci U S A 1984, 81:6149-6153.

188. Golumbek PT, Lazenby AJ, Levitsky HI, Jaffee LM, Karasuyama H, Baker M, Pardoll DM: Treatment of established renal cancer by tumor cells engineered to secrete interleukin-4. Science 1991, 254:713-716.

189. Tepper RI, Pattengale PK, Leder P: Murine interleukin-4 displays potent anti-tumor activity in vivo. Cell 1989, 57:503-512.

190. Yu JS, Wei MX, Chiocca EA, Martuza RL, Tepper Rl: Treatment of glioma by engineered interleukin 4-secreting cells. Cancer Res 1993, 53:3125-3128.

191. Wei MX, Tamiya T, Hurford RK Jr, Boviatsis EJ, Tepper RI, Chiocca EA: Enhancement of interleukin-4-mediated tumor regression in athymic mice by in situ retroviral gene transfer. Hum Gene Ther 1995, 6:437-443. 
192. Okada H, Giezeman-Smits KM, Tahara H, Attanucci J, Fellows WK, Lotze MT, Chambers WH, Bozik ME: Effective cytokine gene therapy against an intracranial glioma using a retrovirally transduced IL-4 plus HSVtk tumor vaccine. Gene Ther 1999, 6:219-226.

193. Okada H, Pollack IF, Lotze MT, Lunsford LD, Kondziolka D, Lieberman F, Schiff D, Attanucci J, Edington H, Chambers W, Robbins P, Baar J, Kinzler D, Whiteside T, Elder E: Gene therapy of malignant gliomas: a phase I study of IL-4-HSV-TK gene-modified autologous tumor to elicit an immune response. Hum Gene Ther 2000, 11:637-653.

194. Prives C, Hall PA: The p53 pathway. J Pathol 1999, 187:112-126.

195. Vogelstein B, Lane D, Levine AJ: Surfing the p53 network. Nature 2000, 408:307-310.

196. Vecil GG, Lang FF: Clinical trials of adenoviruses in brain tumors: a review of Ad-p53 and oncolytic adenoviruses. J Neurooncol 2003, 65:237-246.

197. Lane DP: Cancer. p53, guardian of the genome. Nature 1992, 358:15-16.

198. Levine AJ: p53, the cellular gatekeeper for growth and division. Cell 1997, 88:323-331.

199. Woods DB, Vousden KH: Regulation of p53 function. Exp Cell Res 2001, 264:56-66.

200. Kanu OO, Hughes B, Di C, Lin N, Fu J, Bigner DD, Yan H, Adamson C: Glioblastoma multiforme oncogenomics and signaling pathways. Clin Med Oncol 2009, 3:39-52

201. Bogler $\mathrm{O}$, Huang HJ, Kleihues $P$, Cavenee WK: The p53 gene and its role in human brain tumors. Glia 1995, 15:308-327.

202. England B, Huang T, Karsy M: Current understanding of the role and targeting of tumor suppressor p53 in glioblastoma multiforme. Tumour Biol 2013, 34:2063-2074

203. Li H, Alonso-Vanegas M, Colicos MA, Jung SS, Lochmuller H, Sadikot AF, Snipes GJ, Seth P, Karpati G, Nalbantoglu J: Intracerebral adenovirus-mediated p53 tumor suppressor gene therapy for experimental human glioma. Clin Cancer Res 1999, 5:637-642.

204. Gomez-Manzano C, Fueyo J, Kyritsis AP, Steck PA, Roth JA, McDonnell TJ, Steck KD, Levin VA, Yung WK: Adenovirus-mediated transfer of the p53 gene produces rapid and generalized death of human glioma cells via apoptosis. Cancer Res 1996, 56:694-699.

205. Lang FF, Yung WK, Raju U, Libunao F, Terry NH, Tofilon PJ: Enhancement of radiosensitivity of wild-type $\mathrm{p} 53$ human glioma cells by adenovirusmediated delivery of the p53 gene. J Neurosurg 1998, 89:125-132.

206. Shono T, Tofilon PJ, Schaefer TS, Parikh D, Liu TJ, Lang FF: Apoptosis induced by adenovirus-mediated p53 gene transfer in human glioma correlates with site-specific phosphorylation. Cancer Res 2002, 62:1069-1076.

207. Li H, Lochmuller $H$, Yong WW, Karpati G, Nalbantoglu J: Adenovirus-mediated wild-type p53 gene transfer and overexpression induces apoptosis of human glioma cells independent of endogenous p53 status. J Neuropathol Exp Neurol 1997, 56:872-878.

208. Kock H, Harris MP, Anderson SC, Machemer T, Hancock W, Sutjipto S, Wills KN, Gregory RJ, Shepard HM, Westphal M, Maneval DC Adenovirus-mediated p53 gene transfer suppresses growth of human glioblastoma cells in vitro and in vivo. Int J Cancer 1996, 67:808-815.

209. Cirielli C, Inyaku K, Capogrossi MC, Yuan X, Williams JA: Adenovirus-mediated wild-type p53 expression induces apoptosis and suppresses tumorigenesis of experimental intracranial human malignant glioma. J Neurooncol 1999, 43:99-108.

210. Badie B, Kramar MH, Lau R, Boothman DA, Economou JS, Black KL: Adenovirus-mediated p53 gene delivery potentiates the radiation-induced growth inhibition of experimental brain tumors. J Neurooncol 1998, 37:217-222

211. Van Meir EG, Polverini PJ, Chazin VR, Su Huang HJ, de Tribolet N, Cavenee WK: Release of an inhibitor of angiogenesis upon induction of wild type p53 expression in glioblastoma cells. Nat Genet 1994, 8:171-176.

212. Badie B, Drazan KE, Kramar MH, Shaked A, Black KL: Adenovirus-mediated p53 gene delivery inhibits 9L glioma growth in rats. Neurol Res 1995, 17:209-216

213. Biroccio A, Bufalo DD, Ricca A, D’Angelo C, D'Orazi G, Sacchi A, Soddu S, Zupi G: Increase of BCNU sensitivity by wt-p53 gene therapy in glioblastoma lines depends on the administration schedule. Gene Ther 1999, 6:1064-1072.
214. Shinoura N, Yoshida Y, Asai A, Kirino T, Hamada H: Adenovirus-mediated transfer of p53 and Fas ligand drastically enhances apoptosis in gliomas. Cancer Gene Ther 2000, 7:732-738.

215. Pan D, Wei X, Liu M, Feng S, Tian X, Feng X, Zhang X: Adenovirus mediated transfer of p53, GM-CSF and B7-1 suppresses growth and enhances immunogenicity of glioma cells. Neurol Res 2010, 32:502-509.

216. Lang FF, Bruner JM, Fuller GN, Aldape K, Prados MD, Chang S, Berger MS, McDermott MW, Kunwar SM, Junck LR, Chandler W, Zwiebel JA, Kaplan RS, Yung WK: Phase I trial of adenovirus-mediated p53 gene therapy for recurrent glioma: biological and clinical results. J Clin Oncol 2003, 21:2508-2518

217. Hong YK, Joe YA, Yang YJ, Lee KS, Son BC, Jeun SS, Chung DS, Cho KK, Park CK, Kim MC, Kim HK, Yung WK, Kang JK: Potentials and limitations of adenovirus-p53 gene therapy for brain tumors. J Korean Med Sci 2000, 15:315-322.

218. Chintala SK, Fueyo J, Gomez-Manzano C, Venkaiah B, Bjerkvig R, Yung WK, Sawaya R, Kyritsis AP, Rao JS: Adenovirus-mediated p16/CDKN2 gene transfer suppresses glioma invasion in vitro. Oncogene 1997 15:2049-2057.

219. Dunn GP, Rinne ML, Wykosky J, Genovese G, Quayle SN, Dunn IF, Agarwalla PK, Chheda MG, Campos B, Wang A, Brennan C, Ligon KL, Furnari F, Cavenee WK, Depinho RA, Chin L, Hahn WC: Emerging insights into the molecular and cellular basis of glioblastoma. Genes Dev 2012, 26:756-784.

220. Lu W, Zhou X, Hong B, Liu J, Yue Z: Suppression of invasion in human U87 glioma cells by adenovirus-mediated co-transfer of TIMP-2 and PTEN gene. Cancer Lett 2004, 214:205-213.

221. Abe T, Terada K, Wakimoto H, Inoue R, Tyminski E, Bookstein R, Basilion JP, Chiocca EA: PTEN decreases in vivo vascularization of experimental gliomas in spite of proangiogenic stimuli. Cancer Res 2003, 63:2300-2305.

\section{doi:10.1186/2052-8426-2-21}

Cite this article as: Okura et al:: Gene therapy for malignant glioma.

Molecular and Cellular Therapies 2014 2:21.

\section{Submit your next manuscript to BioMed Central and take full advantage of:}

- Convenient online submission

- Thorough peer review

- No space constraints or color figure charges

- Immediate publication on acceptance

- Inclusion in PubMed, CAS, Scopus and Google Scholar

- Research which is freely available for redistribution 